\title{
Isotope signatures and hydrochemistry as tools in assessing groundwater occurrence and dynamics in a coastal arid aquifer
}

\author{
C. Tamez-Meléndez ${ }^{1,2}$ - A. Hernández-Antonio ${ }^{1}$ - P. C. Gaona-Zanella ${ }^{1}$. \\ N. Ornelas-Soto ${ }^{1} \cdot$ J. Mahlknecht ${ }^{1}$
}

Received: 13 July 2015/Accepted: 7 April 2016/Published online: 5 May 2016

(C) The Author(s) 2016. This article is published with open access at Springerlink.com

\begin{abstract}
Groundwater from the La Paz arid coastal aquifer in Baja California, Mexico, is essentially the only source of drinking water for the local population and tourists, as well as irrigation water for agricultural needs. The intensive exploitation of the aquifer and water cycling has resulted in groundwater abatement (up to $10 \mathrm{~m}$ ) and high salinity (up to $\sim 5800 \mathrm{mg}^{-1}$ ). A study using hydrochemistry, isotopic (deuterium, oxygen-18 and carbon-14) and gaseous tracers (chlorofluorocarbons CFC-11, CFC-12, CFC-113), as well as multivariate statistics, was developed to elucidate groundwater composition, flow and occurrence. Groundwater is of meteoric origin, and a large proportion is subject to evaporation. The primary natural recharge is generated in the El Novillo and Las Cruces ranges, and groundwater subsequently flows in a SE-NW direction toward the coast. The initial water type is the result of discordant dissolution of silicate minerals and ion exchange on soils. In the lower plain portion, the aquifer system is recharged from irrigation return flow and seawater intrusion, which significantly affects groundwater chemistry. Nitrate and chloride concentrations indicate that groundwater is highly affected by an overuse of fertilizers in agricultural activities, but there is little effect from urban activities. Seawater intrusion has progressed rapidly during the past decade, and the impact currently extends $13 \mathrm{~km}$
\end{abstract}

J. Mahlknecht

jurgen@itesm.mx

1 Centro del Agua para América Latina y el Caribe, Tecnológico de Monterrey, Ave. Eugenio Garza Sada 2501, 64849 Monterrey, Mexico

2 Postgraduate Program, Faculty of Geoscience and Geography, University of Göttingen, Goldschmidtstr. 3, 37077 Göttingen, Germany inland. Radiocarbon residence time calculations suggest that groundwater is modern, with the exception of Chametla and El Centerario sites in the central and western lowlands with ages of up to $\sim 5000$ years. These waters indicate an additional recharge source for the upconing of fossil groundwater or regional flow.

Keywords Coastal aquifers · Hydrogeochemistry · Arid regions · Isotope hydrology · Contamination

\section{Introduction}

Coastal areas are preferred places for living because of multiple benefits. According to recent data provided by the United Nations Environmental Program (UNEP), approximately $60 \%$ of the world's population lives within $60 \mathrm{~km}$ of a coast. This proportion will increase to $75 \%$ within the next two decades. Human settlement, together with the development of agricultural, industrial and tourist activities, has adversely impacted coastal water resources (Cardoso da Silva et al. 2010). Moreover, in semiarid and arid coastal regions, groundwater frequently is the sole source of fresh water, and often the periods of highest water demand coincide with the periods of lowest availability (Post 2005; Unsal et al. 2014). This situation can result in groundwater deficits and saltwater intrusion and thus overexploitation and degradation of available freshwater resources. Although salinization of coastal aquifers is mostly due to seawater intrusion, there are other factors that affect the quality of groundwater that are related to geochemical processes and anthropogenic impacts, and hence the importance to differentiate the sources of salinization and behavior of the aquifer in order to reduce 
vulnerability of the aquifer (Han et al. 2014; Kaplan and Muñoz-Carpena 2014).

At least 15 Mexican coastal aquifers are affected by saltwater intrusion; almost all of them are located in the desert northwestern portion of the country (Baja California and Sonora) (CONAGUA 2014). The La Paz region on the Baja California peninsula is an example of a coastal area that is well known for its tourism and relatively high quality of life. La Paz city, the economic and political center of this region, and the surrounding irrigation-based agriculture rely almost entirely on underlying groundwater resources. The population has increased by $2.4 \%$ per year in recent years (CONAPO 2014). The groundwater extraction volumes for water supply have increased as a consequence of demographic growth and development of agriculture and tourism. Official studies show that the annual extraction of groundwater $\left(32\right.$ million $\left.\mathrm{m}^{3}\right)$ is outgrowing the long-term annual recharge (28 million $\left.\mathrm{m}^{3}\right)$, thereby creating a water supply deficit (CONAGUA 2010). The ever-increasing heavy withdrawals have caused groundwater table depressions of up to $10 \mathrm{~m}$ that have led to the reversal of the hydraulic gradient in the La Paz area. The hydraulic gradient reversal has enhanced seawater intrusion and has resulted in an increase of groundwater salinity of up to $4800 \mathrm{mg}^{-1}$ (TDS), especially along the coastal plain (CNA 1997, 1999; CONAGUA 2010). The migration of the groundwater salinity front has progressed from $6 \mathrm{~km}$ inland from the coastline in 2005 (Cruz-Falcón et al. 2013) to $13 \mathrm{~km}$ in 2013 (Gaona-Zanella 2014). According to recent studies (ICF, Fundación FEMSA and GeoAdaptive LLC 2012), the major challenge for sustainability of La Paz is water supply for the residents in sufficient quality and quantity. Thus, a multi-stakeholder program was established recently to address water scarcity and avoid future conflicts.

Previous studies conducted in the La Paz area concentrated on characterization of the aquifer system (CruzFalcón 2007; PRONATURA Noroeste 2010; Cruz-Falcón et al. 2010), identification of seawater intrusion (CNA 2001; Escolero and Torres-Onofre 2007), hydrodynamic simulations (Monzalvo 2010; CONAGUA and UNAM 2010; CIBNOR and UNAM 2011), estimation of water availability (CNA 2002; CONAGUA 2009) and groundwater recharge based on the hydrologic balance (CruzFalcón et al. 2013).

The aim of the present study was to perform a complementary investigation to study groundwater processes by using a suite of hydrochemical, isotopic and gaseous tracer technologies. Hydrochemical and isotope tracers provide valuable tools for evaluation of groundwater. It is well recognized that major and minor chemical elements may give an insight into water-rock interactions as well as anthropogenic influences affecting the groundwater system as demonstrated in numerous studies (Hem 1989; Mahlknecht et al. 2004; Ledesma-Ruiz et al. 2015; Cruz-Fuentes et al. 2014; Hernández-Antonio et al. 2015; Russak et al. 2015), while water isotopes may define groundwater recharge areas, mixing and evaporation sources (Edmunds et al. 2003; Horst et al. 2007; Jiménez-Martínez and Custodio 2008; Mohammed et al. 2014; Gonçalvès et al. 2015), and radiocarbon isotopes residence times of old groundwater and its distribution (Fontes and Garnier 1979; Clark and Fritz 1997; Edmunds and Smedley 2000; Mahlknecht et al. 2006a). More recently, it has been demonstrated that chlorofluorocarbons are useful in evaluating residence times of modern groundwater, mixing patterns and aquifer's vulnerability to contamination (Busenberg and Plummer 1992; Cook et al. 1995; Goody et al. 2006; Mahlknecht et al. 2006b; Horst et al. 2008; Darling et al. 2012).

This study combines the aforementioned tools with the objective to develop a robust groundwater flow concept. The understanding of the complex processes of $\mathrm{La} \mathrm{Paz}$ coastal aquifer represents a valuable and essential tool for the adequate management of the water resources to ensure sustainability and protection of the coastal aquifer system.

\section{Study area}

\section{General settings}

The La Paz aquifer $\left(1275 \mathrm{~km}^{2}\right)$ is located in the valley of La Paz and is part of the state of Baja California Sur (Fig. 1) (Cruz-Falcón 2007). The climate is predominantly arid with an average annual temperature and rainfall of $23^{\circ} \mathrm{C}$ and $265 \mathrm{~mm}$, respectively. Rainfall occurs primarily during summer (August and September) and is mostly associated with tropical storms and cyclones (CONAGUA 2005; CruzFalcón et al. 2011). The mean potential evapotranspiration is approximately $2015 \mathrm{~mm}$ (CONAGUA 2009). The total number of production wells and annual groundwater extraction in the La Paz aquifer is 155 and 32 million $\mathrm{m}^{3}$, respectively. Sixty-eight percent $(68 \%)$ of the extracted groundwater is used for the public urban water supply, $27 \%$ for agriculture, $3 \%$ for livestock and $2 \%$ for industry and other services. The well depths of the production wells vary between 3 and $200 \mathrm{~m}$ (Monzalvo 2010). Crops cover approximately 26,000 ha of the $\mathrm{La} \mathrm{Paz}$ area and include agave, avocado, guava, cotton, garlic, pepper, quelite, tomato and forage, as well as other crops (INEGI 2005).

\section{Geological and hydrogeological settings}

The geomorphological structure of $\mathrm{La} \mathrm{Paz}$ consists of intermountain plains (valleys), table mountains (mesas) and mountain ranges (sierras) with elevations of up to 
(a)

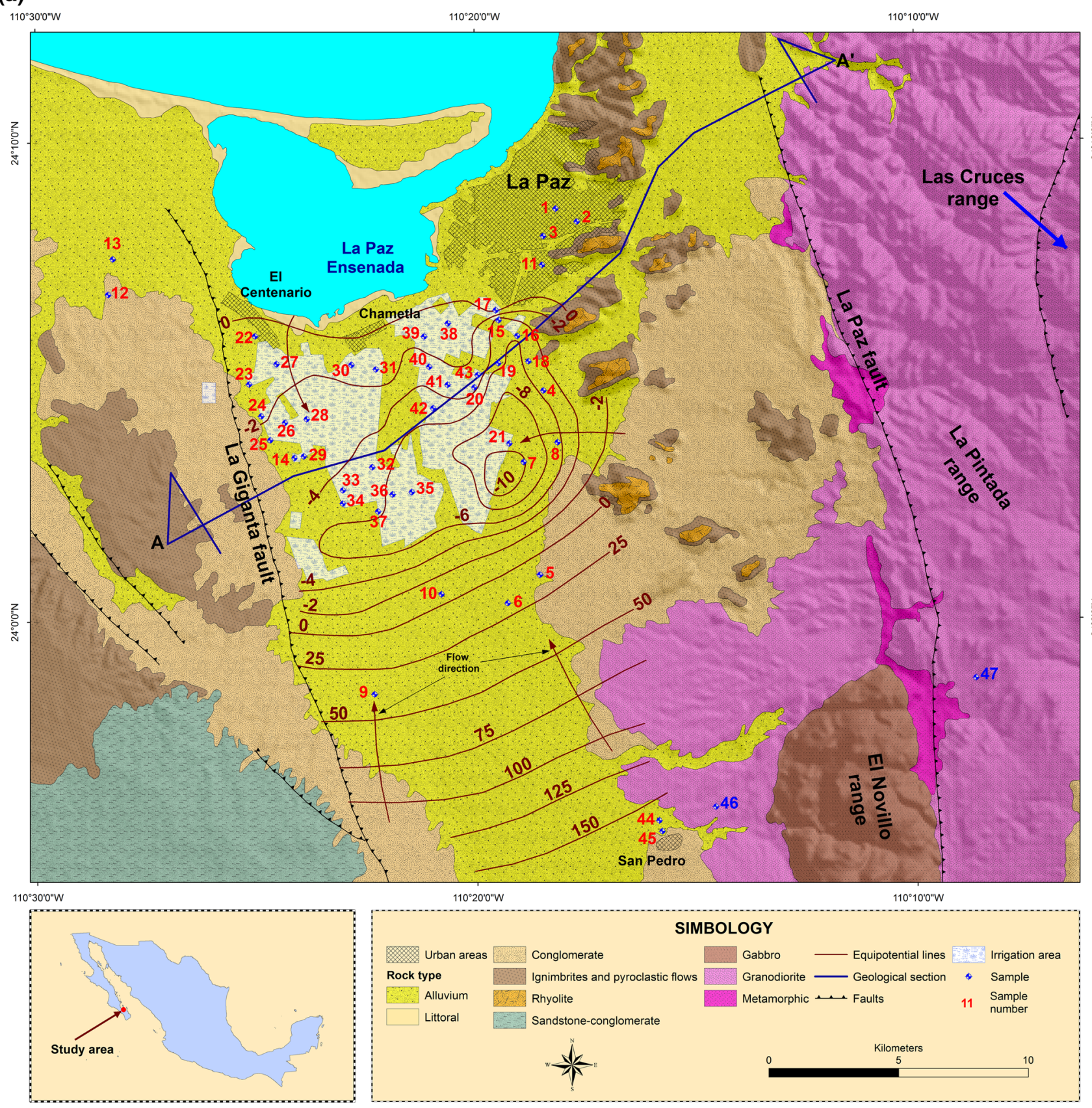

(b)

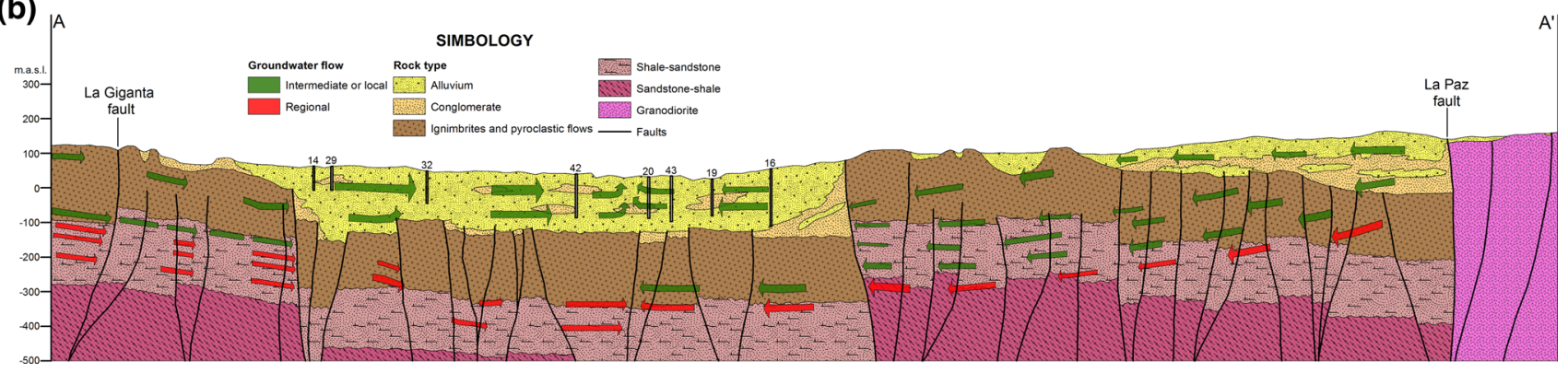

Fig. 1 a Geologic-structural map of the La Paz-El Carrizal valley showing main features, sampled sites and groundwater table elevation (m a.s.1.) for the year 2012; b vertical section as indicated in (a); adapted from CONAGUA (2001) 
$900 \mathrm{~m}$ above sea level (m a.s.l.). The valley of La Paz-El Carrizal (the valley of La Paz) represents a tectonic graben with a $\mathrm{N}-\mathrm{S}$ orientation that is delimited on the $\mathrm{W}$ and $\mathrm{E}$ by the La Giganta and La Paz faults, respectively, and on the north by the Sea of Cortez (Fig. 1a, b). Hypsometric data and the presence of structurally controlled wadies (arroyos) suggest the existence of a series of secondary faults inside the graben (Álvarez et al. 1997; Cruz-Falcón 2007).

The valley of $\mathrm{La} \mathrm{Paz}$ is the result of distention tectonics that created the Gulf of California, probably during the Pleistocene, and the subsequent accumulation of marine and continental granular sediments in the lower topography. The base of the lithologic column in the La $\mathrm{Paz}$ area is a metamorphic complex that consists of Mesozoic shales, phyllites, schists, sillimanite and gneiss (Cruz-Falcón 2007; CONAGUA 2009; Monzalvo 2010). This unit is overlain by Cretaceous intrusive rocks (gabbro, granite and granodiorite) in the Cordillera Oriental portion of the La Paz fault. The basin-fill material of the valley of La Paz consists of Miocene sandstones, conglomerates and fractured volcanic rocks (e.g., Comondú Formation, San Isidro Formation) in the lower part of the valley and alluvial fans (sands, silts, clays) in the upper part of the valley (Fig. 1a, b).

The hydrostratigraphy of the valley includes an uppermost unit that corresponds to non-consolidated, granular sediments and volcanoclastic material with little compaction and medium-to-high permeability. The underlying second unit matches the volcanic flows of the Comondú Formation, with high hydraulic conductivity as a result of fracturing, but is only of local importance due to its discontinuity. These two units represent an unconfined aquifer system approximately $300-400 \mathrm{~m}$ thick and having an average hydraulic conductivity of $1.2-14.3 \times 10^{-3} \mathrm{~m} \mathrm{~s}^{-1}$. Finally, the deeper third unit corresponds to the Pre-Tertiary intrusive rock formations that outcrop in the Cordillera Oriental portion of the study area and have low permeability. The basement of these units is located approximately $900 \mathrm{~m}$ below land surface and consists of a metamorphic complex (CNA 1997, 1999, 2002; CIGSA 2001). This study concentrates on the upper, unconfined aquifer units.

In $\mathrm{La} \mathrm{Paz}$ the catchment recharge represents $15.9 \%$ $(42 \mathrm{~mm})$ of the rainfall in the basin, surface runoff represents $3.6 \%$, and the rest of the rainfall is evaporated. Recharge occurs mostly in the Las Cruces and Novillo ranges located in the E and SSE, respectively, and groundwater flows in a NNW direction (Cruz-Falcón et al. 2011) (Fig. 1a). Groundwater extraction in excess of recharge has caused groundwater abatement. The water table currently slopes from $150 \mathrm{~m}$ a.s.l. in the southern portion of the study area, and from $0 \mathrm{~m}$ a.s.l. in the northern portion close to the sea, to $10 \mathrm{~m}$ below sea level in the central part of the study area, which is indicative of groundwater recharge from seawater intrusion in the central portion (Fig. 1a).

\section{Methods and materials}

\section{Field and laboratory}

Forty-six production wells and one spring were sampled for evaluation of ion chemistry and isotopes in August 2013. Physical parameters, including temperature, $\mathrm{pH}$, electrical conductivity (EC), total dissolved solids (TDS) and dissolved oxygen (DO), were measured in situ using portable meters until measured levels did not vary, allowing for temperature compensations and calibrations with appropriate standards, such as calibration of the $\mathrm{pH}$ meter, which was performed at every sampling site. Alkalinity was determined in the field by titration with $0.02 \mathrm{~N} \mathrm{H}_{2} \mathrm{SO}_{4}$. The groundwater samples were filtered using $0.45-\mu$ membrane filters.

Activation Laboratories LTD, Ontario, Canada, performed the laboratory analyses of major ions and minor ions. Water samples were analyzed for cations $\left(\mathrm{K}^{+}, \mathrm{Na}^{+}\right.$, $\mathrm{Ca}^{2+}, \mathrm{Mg}^{2+}, \mathrm{Sr}^{2+}$ ) using a Perkin Elmer ELAN $9000 \mathrm{ICP} /$ MS and, if upper limits were exceeded, by a Perkin Elmer Optima 3000 ICP OES. Samples were spiked with internal standards to correct for matrix differences over the entire mass range. Additionally, a SLRS-4 and a NIST 1640 standard were run for every 32 samples for quality control. Anions $\left(\mathrm{Cl}^{-}, \mathrm{NO}_{2}{ }^{-}, \mathrm{NO}_{3}{ }^{-}, \mathrm{Br}^{-}, \mathrm{SO}_{4}{ }^{2-}\right.$ and $\left.\mathrm{PO}_{4}{ }^{3-}\right)$ and $\mathrm{SiO}_{2}$ were analyzed by ion chromatography (DIONEX DX-120 Ion Chromatography System). Nitrite concentration was absent (lower detection limit $=0.01 \mathrm{mg} \mathrm{l}^{-1}$ ) in all except one sample $\left(0.3 \mathrm{mg}^{-1}\right)$. This is because nitrite is usually rapidly transformed to nitrate. Phosphate concentration was absent (lower detection limit: $0.02 \mathrm{mg} \mathrm{l}^{-1}$ ). A charge balance error of $10 \%$ was accepted for use in further analyses and interpretations. Duplicates of samples LP10, LP20, LP30, LP40 and LP 41 were re-sampled for quality assurance and quality control.

Stable water isotope ratios in groundwater $\left(\delta^{2} \mathrm{H}, \delta^{18} \mathrm{O}\right)$ were analyzed at Environmental Isotope Laboratory of Tecnológico de Monterrey. A volume of $0.2 \mathrm{ml}$ of water was pipetted into an Exetainer vial and analyzed by a DLT100 Liquid-Water Isotope Analyzer (Los Gatos). The results were determined and reported in the usual delta notation in \%o with respect to the VSMOW standard.

Evaluations of carbon-13 $\left({ }^{13} \mathrm{C}\right)$ ratios, radiocarbon $\left({ }^{14} \mathrm{C}\right)$ activities and chlorofluorocarbon (CFC) concentrations were conducted for 26 representative samples. Carbon-13 determination was performed with a MM-903 spectrometer on carbon dioxide previously released by acidifying sample 
water. The results are reported in $\delta^{13} \mathrm{C}_{\mathrm{DIC}}$ with respect to the VPDB (Vienna Pee Dee Belemnite) standard. The analytical precision was $0.15 \%$. Radiocarbon activity was measured by AMS at the NSF-Arizona Accelerator Facility and is reported as percent modern carbon (pmC). The analytical precision $(1-\sigma)$ ranged from 0.2 percent modern carbon (pMC) for pMC values near 30 , to $0.5 \mathrm{pMC}$ near $100 \mathrm{pMC}$.

Chlorofluorocarbon (CFC-11, CFC-12 and CFC-113) content was analyzed at Spurenstofflabor, Wachenheim, Germany, by gas chromatography with an electron capture detector after preconcentration using a purge-and-trap technique (Oster et al. 1996). The concentrations are reported in pmol $1^{-1}$. The analytical precision $(1-\sigma)$ ranged from $0.05 \mathrm{pmol}^{-1}$ for pmol $1^{-1}$ values near 0 , to 3 pmol $1^{-1}$ near 12 pmol $^{-1}$.

\section{Interpretation}

A bivariate method, the Pearson correlation analysis, was applied for a preliminary evaluation of relation between two hydrochemical parameters. High correlation coefficients approximating 1 or -1 in combination with low significance levels $(p<0.05)$ represented a significant correlation. A hierarchical cluster analysis (HCA) grouped samples according to their similarity. Parameters were progressively merged into clusters, beginning with individual elements of a data set. Each agglomeration step used the distance between clusters from the previous agglomeration. A dendrogram helped to graphically identify the genealogical relationship between clusters and elements. The results were proved for geographic correspondence. All statistical analyses were performed using the Minitab 17.0 program (Minitab 2013).

Deuterium excess $(d)$ was calculated with the formula $d=\delta^{2} \mathrm{H}-8 \delta^{18} \mathrm{O}$. On the one hand, the values of $d$ tend to increase when there is a high kinetic isotope fractioning during evaporation of sea water due high temperatures and dryness of the environment; on the other hand, the effect of evaporation before recharge will lead to a decrease of these values; therefore, this parameter was used as an indicator of vapor origins (Rindsberger et al. 1983; Jiménez-Martínez and Custodio 2008).

Lumped parameter models (LPMs) have been applied to support the interpretation of CFC tracers. The TracerLPM (USGS 2014) was used to evaluate groundwater age distributions and residence times with the LPMs most commonly used in previous studies (IAEA 1996; Plummer et al. 2001; Plummer 2003, 2005; Goody et al. 2006). Ages were corrected for a recharge temperature of $23{ }^{\circ} \mathrm{C}$, a recharge altitude of $208 \mathrm{~m}$ a.s.l. and a salinity in \%o (IAEA 2006). A recharge altitude was selected based on the study of Cruz-Falcón et al. (2011), which indicated that the recharge area is mostly in the El Novillo and Las Cruces ranges.

Radiocarbon data were used to evaluate older ( $>1 \mathrm{ka})$ groundwater in La Paz. Unadjusted ${ }^{14} \mathrm{C}$ ages were calculated from measured ${ }^{14} \mathrm{C}$ activities of dissolved inorganic carbon (DIC) using the Libby half-life (5568 years) and assuming an initial ${ }^{14} \mathrm{C}$ activity $\mathrm{A}_{0}$ of 100 modern carbon $(\mathrm{pmC})$, except for samples of recently recharged water, whose initial activity was set at $105 \mathrm{pmC}$. Age adjustments were made using the formula-based inorganic adjustment models (Ingerson and Pearson 1964; Fontes and Garnier 1979-F\&G). Alkalinity, pH, water temperature and carbon isotope $\left({ }^{13} \mathrm{C}\right.$ and $\left.{ }^{14} \mathrm{C}\right)$ data were used to make these age calculations. The model approach corrects the age for dissolution with "dead" carbon derived from the aquifer matrix, assuming the following parameters to account for the pristine arid sarcocauleschent scrub vegetation (Perea et al. 2005; Michener and Lajtha 2007; Rodríguez-Estrella et al. 1998): initial activity; isotope fractionation factors after Vogel et al. (1970), Mook et al. (1974) and Deines et al. (1974); $\delta^{13} \mathrm{C}$ carbonates of $0 \%$ VPDB and $\delta^{13} \mathrm{C}$ soil $\mathrm{CO}_{2}$ of $-19 \%$ VPDB. If a particular model resulted in an unreasonable (negative) age, the adjusted age was designated as either modern (recharge after the mid-1950s), premodern (recharge prior to the mid-1950s), or as a mixture of modern and pre-modern water with respect to ${ }^{14} \mathrm{C}$ based on evaluating CFC tracers (Gardner and Heilweil 2014).

\section{Results}

\section{Groundwater chemistry}

The physical, chemical and isotopic data for the groundwater samples are summarized in Table 1. Pearson method indicates that positive correlations exist between several hydrochemical parameters. The correlation between $\mathrm{Mg}^{2+}$, $\mathrm{Ca}^{2+}, \mathrm{Sr}^{2+}, \mathrm{Cl}^{-}$and $\mathrm{Br}^{-}$ions is highly significant $(R>0.9 ; p<0.01)$. Meanwhile, $\mathrm{Na}^{+}$is significantly correlated with $\mathrm{Cl}^{-}$and $\mathrm{Br}^{-}(R>0.9 ; p<0.01)$. TDS present a highly significant correlation with alkali and earth alkali $\left(\mathrm{Na}^{+}, \mathrm{Mg}^{2+}, \mathrm{Ca}^{2+}, \mathrm{Sr}^{2+}\right)$, as well as $\mathrm{Cl}^{-}$and $\mathrm{Br}^{-}$ions. None of the samples showed significant negative correlation.

The classification of water samples was performed using HCA with 17 variables $(\mathrm{pH}$, temperature, EC, TDS, DO, alkalinity, $\mathrm{Na}^{+}, \mathrm{SiO}_{2}, \mathrm{~K}^{+}, \mathrm{Ca}^{2+}, \mathrm{Sr}^{2+}, \mathrm{Cl}^{-}, \mathrm{Br}^{-}, \mathrm{NO}_{3}{ }^{-}$, $\mathrm{SO}_{4}{ }^{2-}, \delta^{2} \mathrm{H}, \delta^{18} \mathrm{O}$ and the distance of the sample location from the coastline). Ward́s linkage rule was applied for iteratively linking nearby clusters using a similarity matrix and performing an ANOVA to evaluate the distance between clusters (Ward 1963). The water samples merged into three groups at the phenon line shown in the 


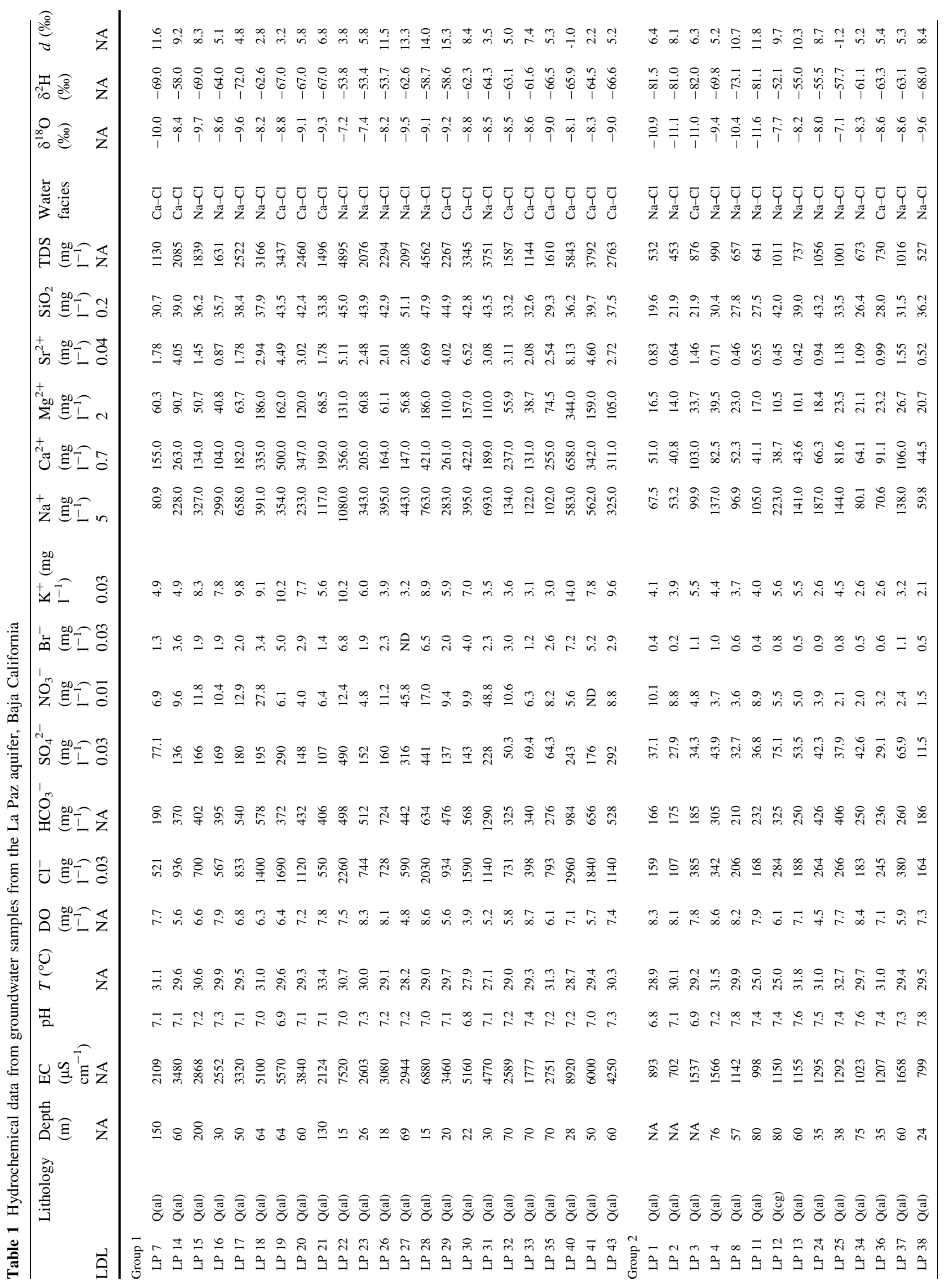




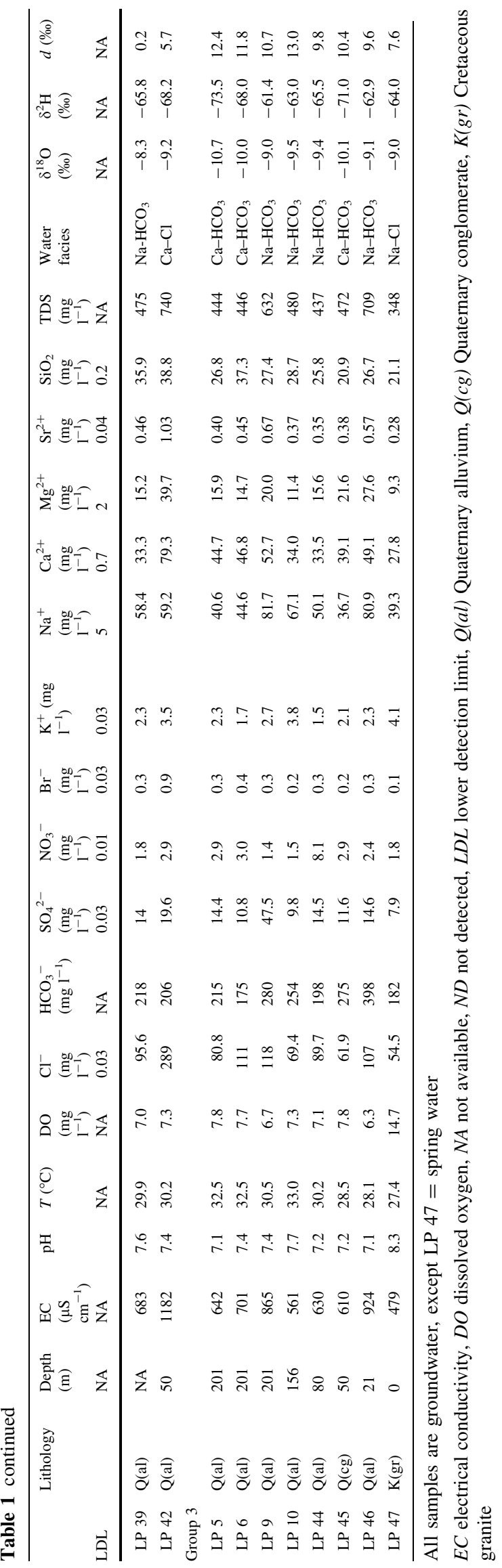

dendrogram (Fig. 2) with geographical correspondence. Group 1 (23 samples) is located in the central part of the study area (south of El Centenario and Chametla) where agriculture is practiced and groundwater extractions from supply wells are high. Group 2 includes 16 samples located mostly in the urbanized area of La Paz. This group is similar to group 3 considering the statistical approach (Fig. 2); however, based on groundwater chemistry (Figs. 4, 5) it lies between group 1 and group 3. All samples of groups 1 and 2 are located in the $20-\mathrm{km}$ fringe of the coastal area. Finally, group 3 consists of 8 samples that are located at higher altitudes and further away from the coastline. They are closer to the recharge areas (Las Cruces and El Novillo ranges). The three groups will be used and discussed in the subsequent hydrogeochemical evaluation.

The study area exhibits a wide range of salinities, ranging from very fresh $\left(479 \mu \mathrm{S} \mathrm{cm}^{-1}\right)$ to brackish $\left(8920 \mu \mathrm{S} \mathrm{cm}^{-1} ; \quad \sigma=2047 \mu \mathrm{S} \mathrm{cm}^{-1}\right.$ ), having slightly acidic to alkaline $\mathrm{pH}$ values between 6.8 and $8.3(\sigma=0.3)$. High EC values are primarily due to elevated $\mathrm{Cl}^{-}, \mathrm{Na}^{+}$and $\mathrm{Ca}^{+}$concentrations that increase from the recharge area (group 3) to the coastal area (group 1) between El Centenario and La Paz (Fig. 3a). Exceptions are water samples LP38 and LP39 from group 2, which are located in the coastal area but have low $\mathrm{Cl}^{-}$concentrations (164 and $95.6 \mathrm{mg}^{-1}$, respectively) in comparison to the rest of the group. The locations of the wells where these samples were collected coincide with an area where artificial recharge takes place, i.e. the wastewater treatment plant of the city of La Paz exchanges treated wastewater with farmers from Centenario and Chametla that, together with Paraiso del Mar, receive 6 million cubic meters per year (CONAGUA 2010). The pH-EC relationship indicates an inverse correlation that reflects the drainage of non-carbonate rocks and sediments. The temperatures range from 25.0 to $33.4{ }^{\circ} \mathrm{C}(\sigma=1.7)$ Elevated temperature values were measured in samples LP05, LP06 and LP10 a subgroup of group three wells, and LP25 of group 2, possibly indicating a slight upconing of deeper, regional groundwater flows from lower, intrusive rock formations. An effect of groundwater warming due to direct influence of air temperature in the wells may be excluded because all wells were tube wells, i.e. not open.

The molar $\mathrm{Na} / \mathrm{Cl}$ ratio of groundwater compared to seawater (0.86) varies from 0.19 to 1.49 (median 0.67) and indicates that some waters $(19 \%)$ are enriched in $\mathrm{Na}^{+}$, which means that molar $\mathrm{Na}^{+}$concentration is in excess of $\mathrm{Cl}^{-}$, while most are depleted. The important depletion of $\mathrm{Na}^{+}$reflects large evaporation effects from water recycling probably linked to agricultural practices. Moreover, the enrichment of $\mathrm{Na}^{+}$indicates weathering of silicates. Another less important mechanism of $\mathrm{Na}^{+}$enrichment or depletion is cation exchange in soils. Sodium is possibly 
Fig. 2 Classification by dendrogram using the Ward's method. The phenon line indicates the decision criteria

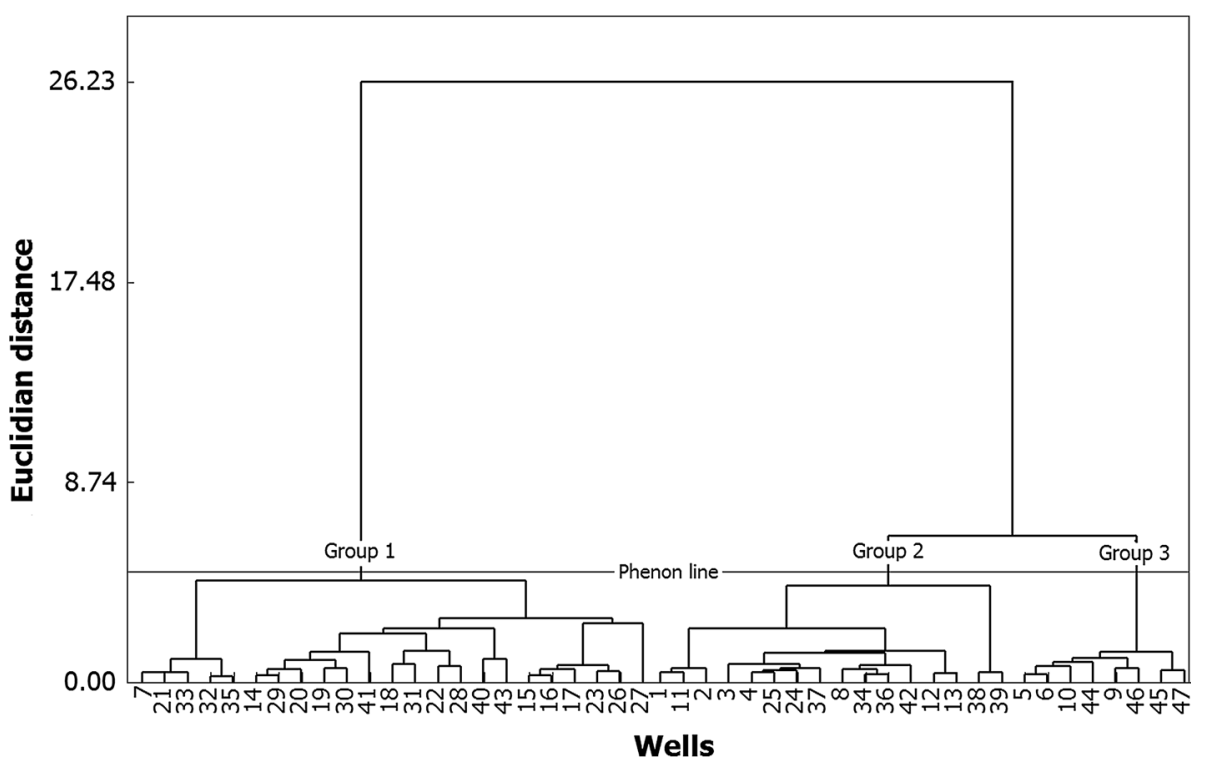

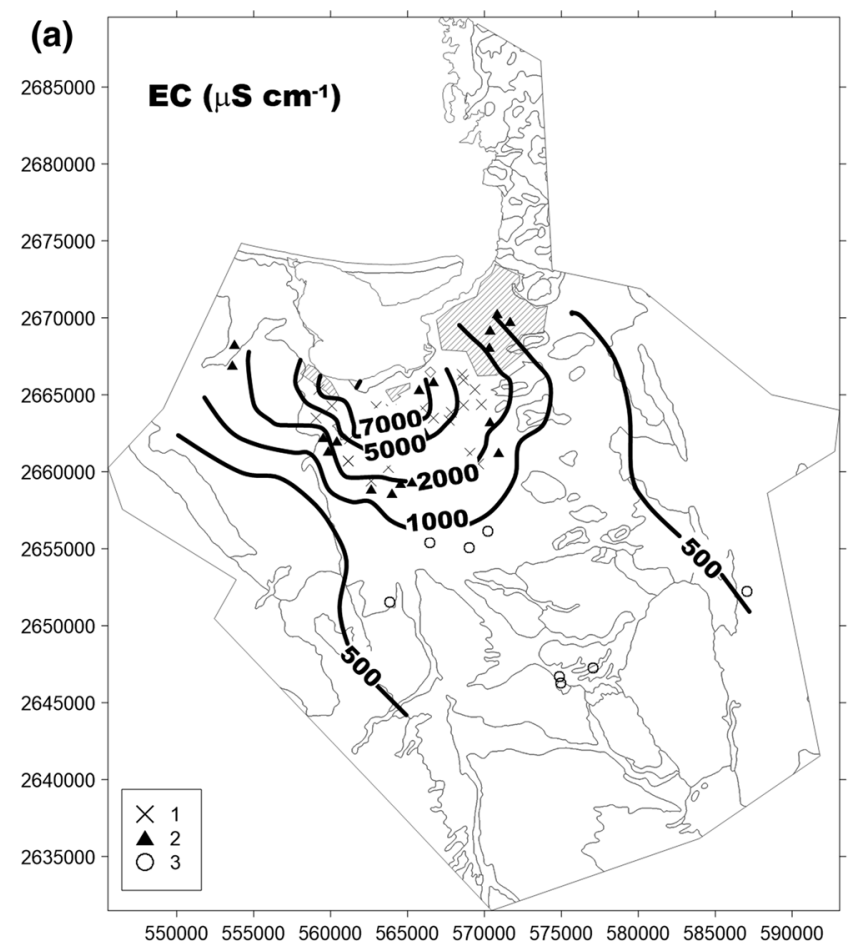

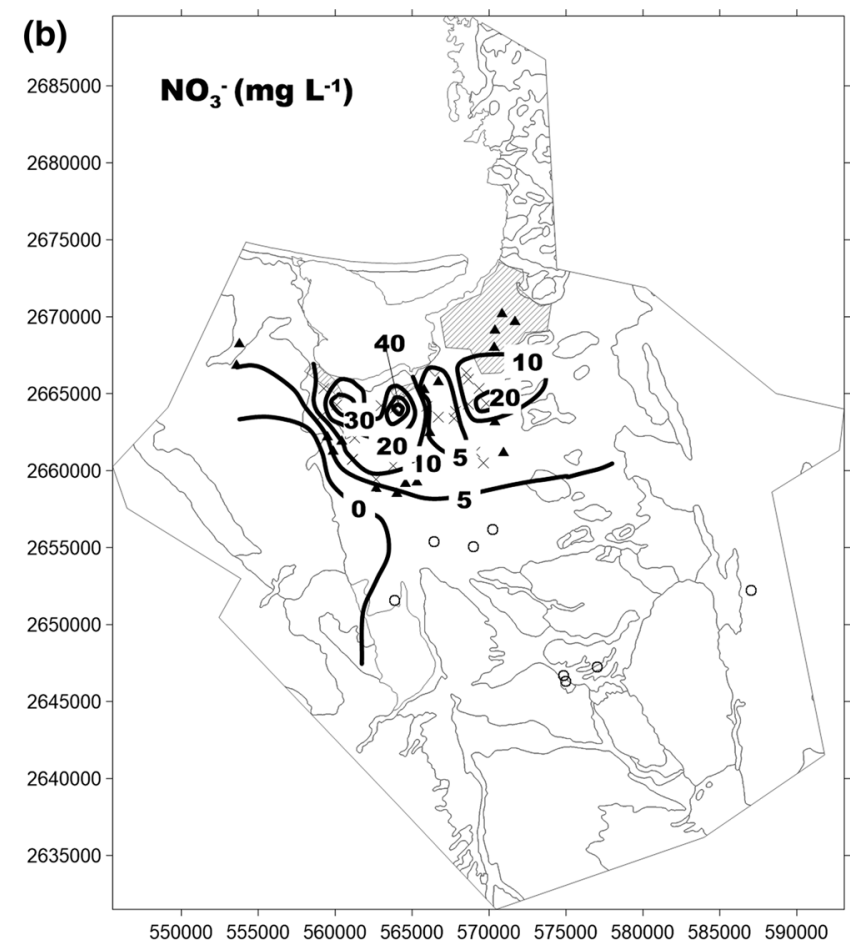

Fig. 3 Distribution of a electrical conductivity and $\mathbf{b}$ nitrate in groundwater. Including geological features, urban areas (hatched areas) and well sites (group symbols)

enriched by exchange of $\mathrm{Ca}^{2+}$ for $\mathrm{Na}^{+}$ions at clay surfaces, which produces $\mathrm{Na}-\mathrm{HCO}_{3}$ waters (e.g., LP9, LP10). Finally, $\mathrm{Na}^{+}$is possibly depleted from solution by reverse ion exchange reactions of $\mathrm{Na}^{+}$for $\mathrm{Ca}^{2+}$ and/or $\mathrm{Mg}^{2+}$ ions at clay surfaces in discharge areas (e.g., LP19, LP20).

Nitrate concentrations $\left(\mathrm{NO}_{3}-\mathrm{N}\right)$ range from 1.4 to $48.8 \mathrm{mg} \mathrm{l}^{-1}\left(\sigma=9.7 \mathrm{mg} \mathrm{l}^{-1}\right)$. Eleven out of 47 samples (23\%) do not comply with the Mexican drinking water standard for $\mathrm{NO}_{3}{ }^{-}-\mathrm{N}\left(10 \mathrm{mg} \mathrm{l}^{-1}\right)$. Samples with values exceeding the standard are mostly located in two agricultural zones south of El Centenario and Chametla, and south of La Paz (part of group 1) (Fig. 3b). Sulfate concentrations vary from 7.9 to $490 \mathrm{mg} \mathrm{l}^{-1}\left(\sigma=114 \mathrm{mg} \mathrm{l}^{-1}\right)$ and increase towards the coastal areas. Chloride concentrations and EC values indicate a similar trend. Two samples do not comply with the Mexican drinking water standard for 
$\mathrm{SO}_{4}{ }^{2-} \quad\left(400 \mathrm{mg} \mathrm{l}^{-1}\right)$. The values of alkalinity $\left(\mathrm{HCO}_{3}{ }^{-}=166-1290 \mathrm{mg} \mathrm{l}^{-1} ; \sigma=219 \mathrm{mg} \mathrm{l}^{-1}\right)$ and major cations tend to increase considerably towards the coastline.

The chloride-to-bromide mass ratio $(\mathrm{Cl} / \mathrm{Br})$ in seawater is typically $285 . \mathrm{Cl} / \mathrm{Br}$ ratios in coastal groundwaters are typically close to 290 (Davis et al. 1998; Anders et al. 2014). Since $\mathrm{Br}$ is slightly more soluble than $\mathrm{Cl}$, the $\mathrm{Cl} / \mathrm{Br}$ ratio in evaporates (halites, gypsum) decreases due to evaporative effects. In consequence, the dissolution of these rocks may increase the ratio to 4000 (Davis et al. 1998; Anders et al. 2014). Wastewater loaded with $\mathrm{NaCl}$ may increase the ratio up to 655 . Finally, the ratio may be decreased to 130 by the use of Br-based pesticides or leaching farm-animal or septic waste (Alcalá and Custodio 2008). The $\mathrm{Cl} / \mathrm{Br}$ for groundwater samples ranges from 245 to 629 (mean $=364)$ (Fig. 4). Most samples close to sea have ratios higher than seawater; they are likely the result of evaporation of seawater. Some samples close to sea that have ratios lower than seawater may be indicative of animal farming. In general the samples are in the expected range of arid coastal aquifers.

A piper diagram elucidates the chemical patterns (Fig. 5). The general dominance of cations is $\mathrm{Na}>\mathrm{Ca}=\mathrm{Mg}>\mathrm{K}$, while the dominance of anions was $\mathrm{Cl}>\mathrm{HCO}_{3}>>\mathrm{SO}_{4}$. The central diamond in the diagram shows a clear distinction between the three selected groups. Group $1(\mathrm{Ca}-\mathrm{Cl}$ and $\mathrm{Na}-\mathrm{Cl})$ near the coastline is characterized by seawater intrusion, and a trend towards elevated $\mathrm{SO}_{4}, \mathrm{Cl}$ and $\mathrm{NO}_{3}$ values indicates contamination by agricultural practices. Group $3\left(\mathrm{Ca}-\mathrm{HCO}_{3}\right.$ and $\left.\mathrm{Na}-\mathrm{HCO}_{3}\right)$ is derived from rainwater and spreads along the $\mathrm{HCO}_{3}$ facies type as it infiltrates the ground surface and undergoes weathering processes. Finally, group 2 represents a transition between both groups 1 and 3 .

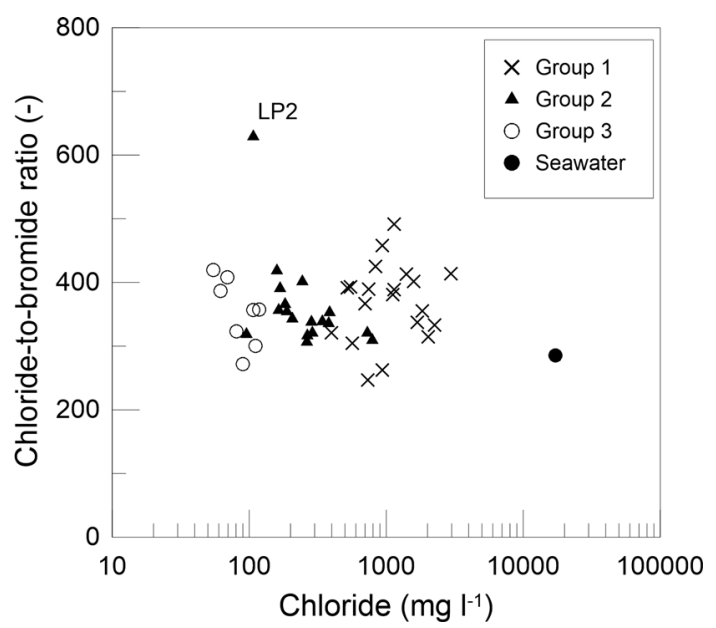

Fig. $4 \mathrm{Cl} / \mathrm{Br}$ mass ratios versus $\mathrm{Cl}^{-}$for the three groundwater groups and seawater

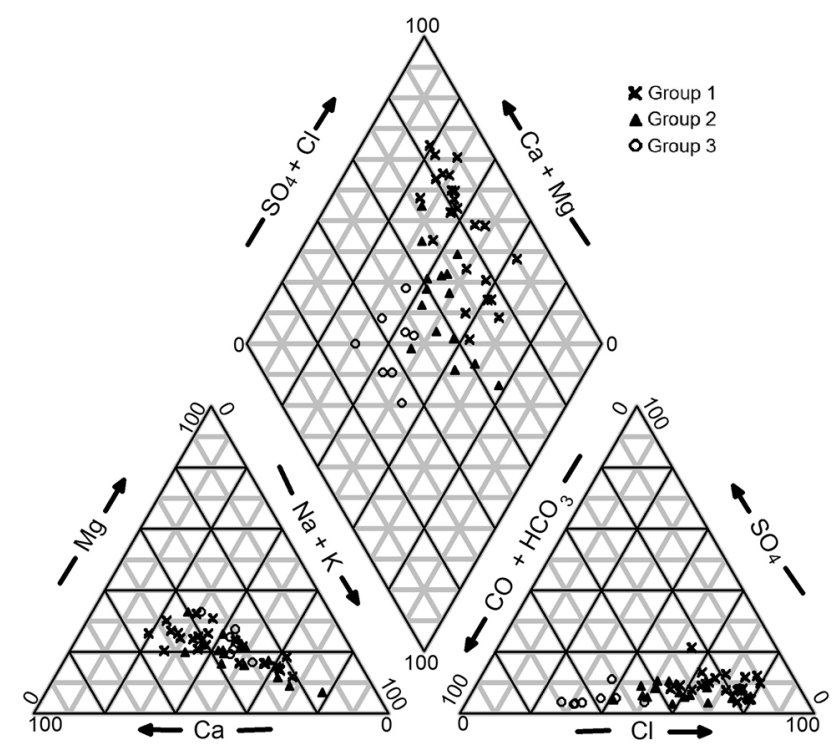

Fig. 5 Trilinear diagram. Circles represent the first group of samples. Triangles represent the second group. Crosses represent the third group

\section{Stable water isotopes and deuterium excess}

The $\delta^{18} \mathrm{O}$ and $\delta^{2} \mathrm{H}$ values vary from -11.6 to $-7.1 \%$ $(\sigma=1.0 \%)$ and from -82.0 to $-52.1 \%$ o $(\sigma=7.2 \%$ ), respectively (Table 1). Plotted in a conventional diagram, the general trend is $\delta^{2} \mathrm{H}=6.28\left(\delta^{18} \mathrm{O}\right)-8.47 ; r^{2}=0.78$ (Fig. 6). It indicates that the samples are plotted mostly along and below the Regional Meteoric Water Line (RMWL) according to the Chihuahua IAEA GNIP station: $\delta^{2} \mathrm{H}=7.1 \delta^{18} \mathrm{O}+2.8$ (Wassenaar et al. 2009). These $\delta^{18} \mathrm{O}$ and $\delta^{2} \mathrm{H}$ data indicate that groundwater in the coastal aquifer is of meteoric origin and a large proportion is subject to evaporation effects which is consistent with deuterium excess. Waters located at higher altitudes (group 3) plot along the RMWL, indicating direct infiltration of local precipitation with little evaporation. Deuterium excess for this group varies from 7.6 to 12.9 with an average of $10.6 \%$ ( $\sigma=1.73 \%$ ) showing an increment of $d$ values as temperature increases due to kinetic isotope fractioning related to high temperatures and dryness in the environment (Jiménez-Martínez and Custodio 2008). Group 2 shows a high variability of $\delta^{18} \mathrm{O}$ and $\delta^{2} \mathrm{H}$ values, which is similar to the values of the other two groups. A notable exception is a cluster of four samples representing the urban area of La Paz (LP1, LP2, LP3 and LP11). These samples show the most depleted $\delta^{18} \mathrm{O}$ and $\delta^{2} \mathrm{H}$ values of the study area, indicating groundwater recharge in higher altitudes (Figs. 1a, 6). Finally, group 1 shows the least depleted $\delta^{18} \mathrm{O}$ and $\delta^{2} \mathrm{H}$ values among all groups. The samples of group 1 and 2 have a similar distribution and deuterium excess values: from -0.1 to 15.2 , and from -1.1 

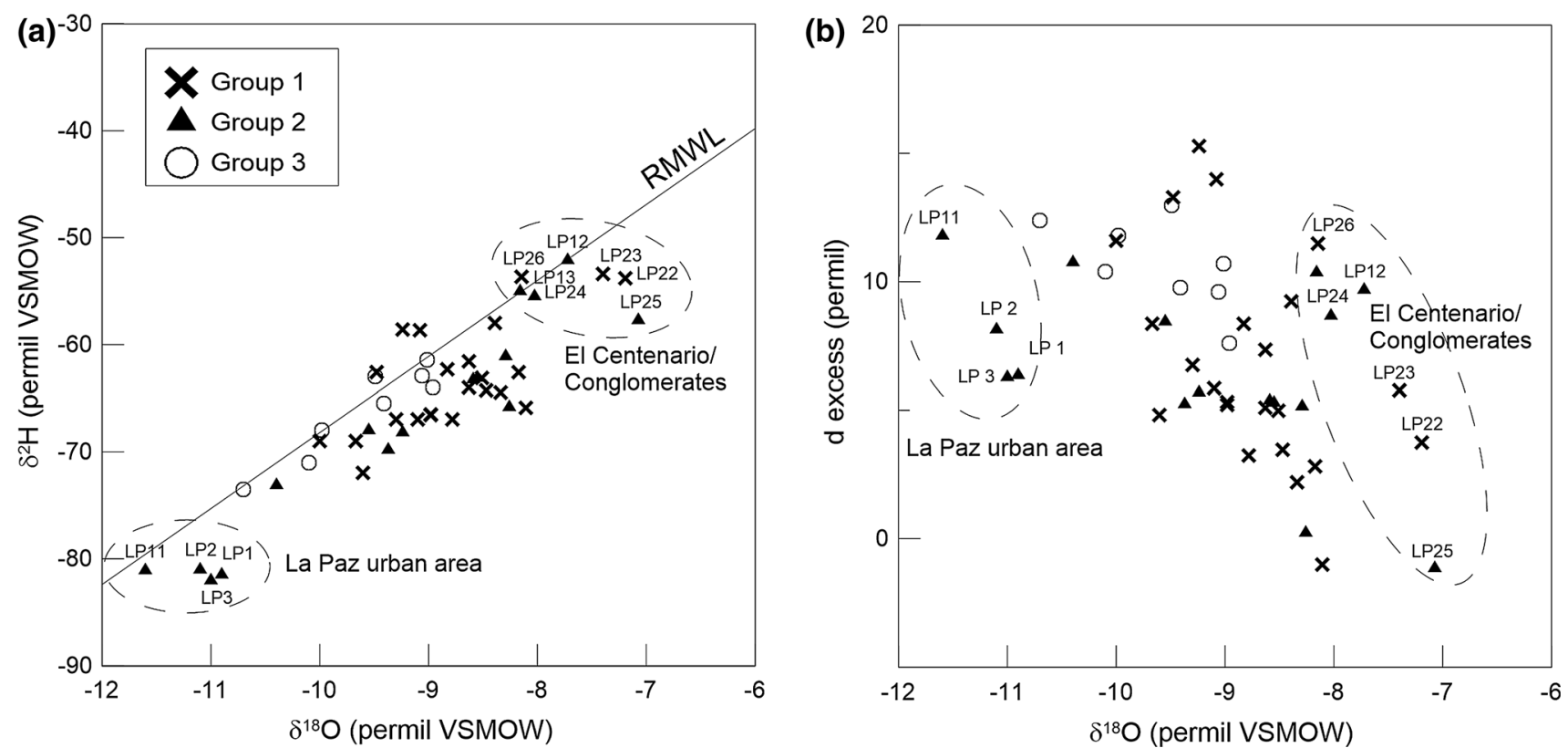

Fig. 6 a Stable water isotope diagram of groundwater samples and regional meteoric water line (RMWL) according to the Chihuahua IAEA GNIP station; b oxygen-18 vs. deuterium excess

to $11.8 \%$, respectively. These samples are plotted on and below the RMWL (El Centerario and Chametla) which is consistent with the extensive evaporation before and during recharge in the sample area due to dry conditions and the heavy extraction and cycling of groundwater to supply the area with irrigation water. Waters plotted below the RMWL are the most mineralized. The area in which they are located is characterized by low infiltration rates and long residence times over land compared to other areas (Cruz-Falcon et al. 2011), which is congruent with their isotopic signature. Waters from the locality of El Centenario (LP22, LP23 and LP27) are derived from recharge of the western conglomerates (LP12, LP13). These samples show the most mineralogically enriched values in the study area, indicating lower altitude and/or less humid climate conditions during recharge (Fig. 6). The $\delta^{18} \mathrm{O}$ and $\delta^{2} \mathrm{H}$ values and water chemistry are affected in contaminated or saline groundwater. Brackish groundwater with enriched ${ }^{18} \mathrm{O}$ values and high $\mathrm{Cl}^{-}$or $\mathrm{NO}_{3}{ }^{-}$concentrations is indicative of evaporation effects in agricultural lands, as observed in samples LP18, LP27, LP28 and LP31. Groundwater from the urban area of La Paz (LP1, LP2, LP3 and LP11) exhibits relatively low $\mathrm{Cl}^{-}$and $\mathrm{NO}_{3}{ }^{-}$ values, suggesting little influence from domestic sewage.

\section{Groundwater age dating}

Trace gases $\mathrm{CCl}_{3} \mathrm{~F}$ (CFC-11), $\mathrm{CCl}_{2} \mathrm{~F}_{2}$ (CFC-12), $\mathrm{C}_{2} \mathrm{Cl}_{3} \mathrm{~F}_{3}$ (CFC-113) and $\mathrm{SF}_{6}$ (sulphur hexafluoride) are increasingly used as tracers of young (e.g., up to decades old) groundwater. The principle of age dating with CFCs is based on comparing their concentrations in groundwater with the known worldwide atmospheric concentrations of these anthropogenic gases over the past 60 years to estimate the year of recharge at each site (Darling et al. 2012). However, several complications may arise. Local sources of trace gases from cities and industries, sorption or even the sampling process may bias the levels of CFCs (Plummer et al. 2001). Microbial degradation may also occur under reducing conditions (Cook et al. 1995; Plummer et al. 1998).

Chlorofluorocarbon mixing ratios in the study area ranged from 45.7 to 2479 (CFC-11), 93 to 1587 ( $\sigma=413)$ (CFC-12) and 10 to 318 (CFC-113) pptv (Table 2). The highest CFC-12 values were indicated for samples located in irrigation areas (LP28, LP42), although elevated values are also indicated in samples located towards the El Novillo range (LP4, LP8 and LP18) and in El Centenario (LP22) (Fig. 7a). CFC-11 values indicate a notable deviation from $\mathrm{CFC}-12$ values and also from $\mathrm{CFC}-113$ values. CFC-12 and CFC-113 values are more consistent. Disagreement between tracers is expected for groundwater samples because the amount of increase in CFC concentrations due to contamination is considered to be different for each CFC gas (Horst et al. 2008; Kusano et al. 2014).

The tracer pairs of CFC-12 and CFC-113 in Fig. 8a generally plot within the regions bounded by the piston flow and exponential mixing models. In Fig. 8b, the samples generally plot below the exponential mixing model curve. This lower CFC-11/CFC-12 ratio may be due to 


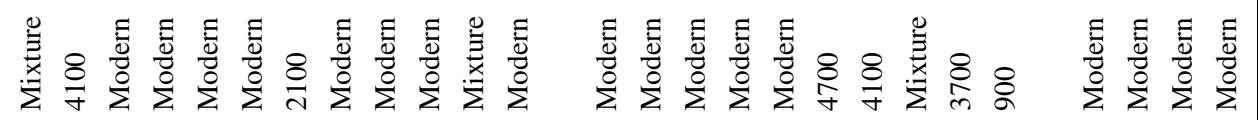

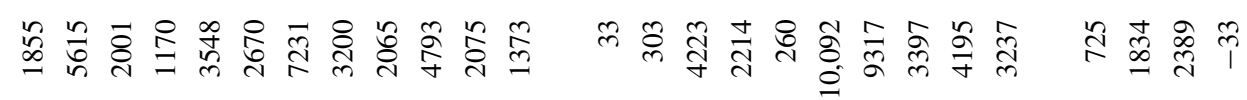

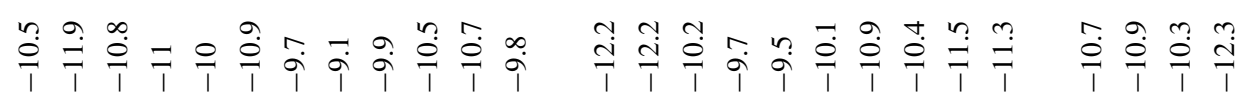
$\rightarrow$

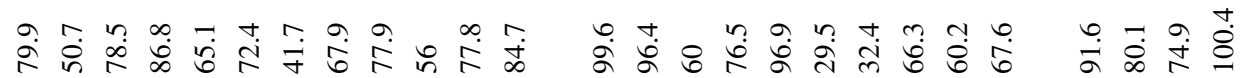

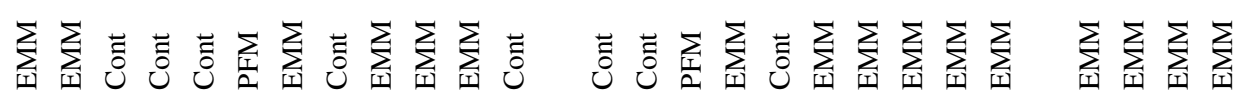

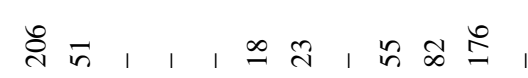

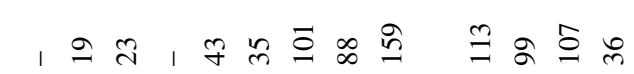

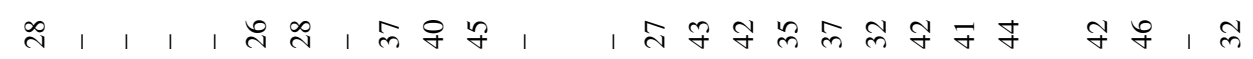

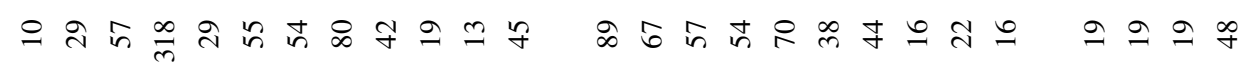

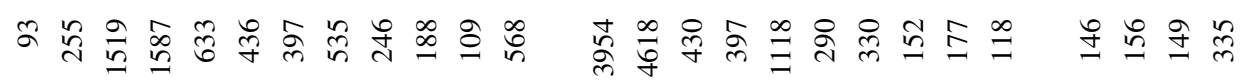

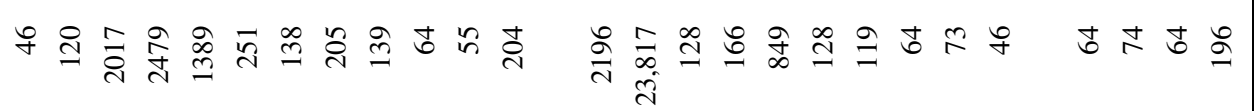

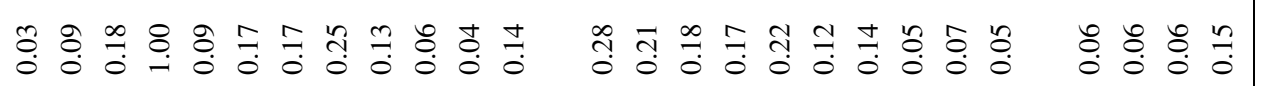

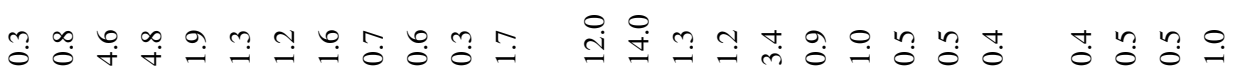

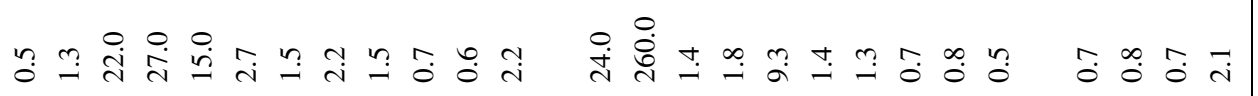

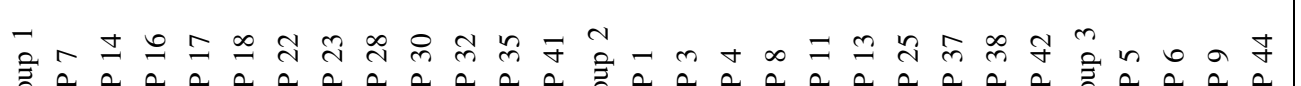



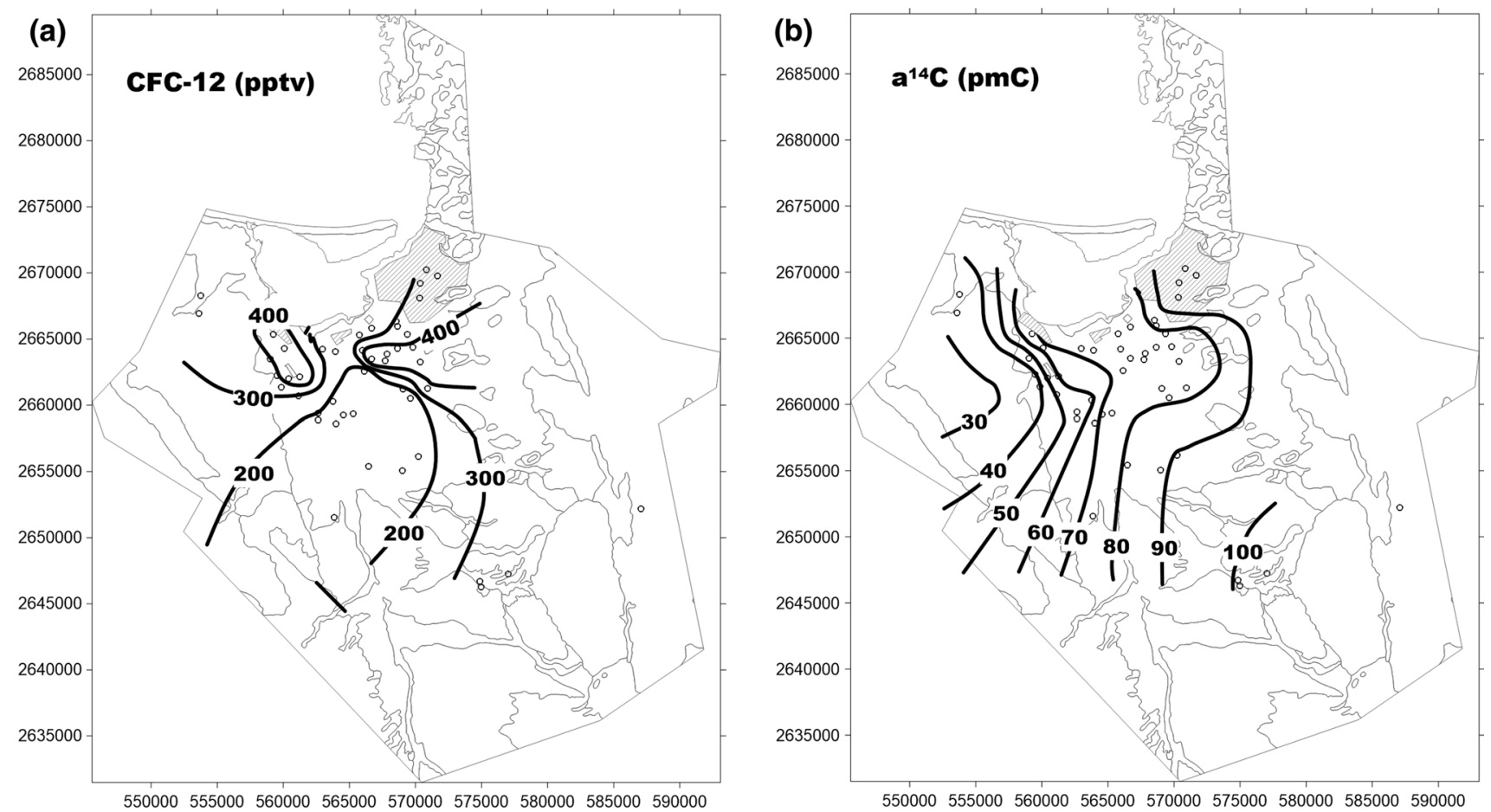

Fig. 7 Distribution of a CFC-12 mixing ratio and $\mathbf{b}$ radiocarbon activity in groundwater. Including geological features, urban areas (hatched areas) and well sites (circles)

microbial degradation of CFC-11, as also observed in previous studies (e.g., Lindsey et al. 2003; Horst et al. 2008). It has been demonstrated that CFC-12 and CFC-113 are less degraded in waters (e.g., Plummer and Busenberg 2000). However, in our study no individual sample indicated dissolved oxygen concentrations of $<3 \mathrm{mg} \mathrm{l}^{-1}$, which indicates that aerobic conditions predominate. One explanation of this discrepancy could be that only part of the flow paths arriving at a sampled well underwent anaerobic conditions, or oxygenation occurred in the well tube. Moreover, the different CFC tracers have distinct temporal patterns of their input functions. The air-mixing ratios of CFC-11 and CFC-113 indicate a turnover in the 1990s, which leads to ambiguity in age dating with modern ages that span the 1990s. Thus, in this study the estimation of residence times was performed using only CFC-12 tracers.

The estimation of groundwater residence times (RTs) requires the knowledge of the aquifer geometry. The most commonly used models are piston flow and exponential mixing. Although hybrid models are also feasible, such as exponential piston flow models, they were not considered due to a lack of detailed knowledge of aquifer conditions at individual wells. The investigated area represents an aquifer that is primarily unconfined with well depths of up to $200 \mathrm{~m}$ and long screen lengths. This geometry indicates that the exponential mixing model may generally match the groundwater conditions rather than the piston flow model.
The tracer plot in Fig. 9a confirms this assumption. The individual samples do not plot on the piston flow curve, with the exception of a few dispersed samples (LP4 and LP22).

The RTs calculated with the TracerLPM model range from 26 to 46 years and 18 to 206 years for PFM and EMM, respectively (Table 2). Samples with CFC concentrations greater than levels of possible atmospheric equilibrium for the northern hemisphere were considered to have been contaminated by excess air and were not used for RT calculations.

Carbon-13 values range from -12.3 to $-9.5 \%$ VDBP, and ${ }^{14} \mathrm{C}$ activities vary between 29.5 and $100.5 \mathrm{pmC}$ (Table 2). Uncorrected RTs vary from recent to $10 \mathrm{ka}$. Radiocarbon data indicate a trend from elevated levels in the eastern mountainous flanks to lower levels in the western extremes (Fig. 7b). The highest values on the order of 100 pmC mostly represent groundwater recharged in the flanks of the El Novillo range/La Paz fault in the eastern portion of the study area (e.g., LP1, LP3 and LP44). These waters consistently indicate a depleted $\delta^{13} \mathrm{C}$ signature and low EC, $\mathrm{Cl}$ and DIC values (Fig. 9a, b). Two trends can be observed in Fig. 9b: group 2 and 3 waters reduce ${ }^{14} \mathrm{C}$ activities with increasing DIC/salinity, and group 1 waters raise ${ }^{14} \mathrm{C}$ values with increasing DIC/salinity. This rise in ${ }^{14} \mathrm{C}$ values may be explained by the increased admixture of seawater and evaporation in group 1 that increases DIC/ salinity. 
The corrected values in Table 2 suggest that groundwater is modern with the exception of several sites (LP13, LP14, LP23, LP25, LP38 and LP42). These waters (0.9

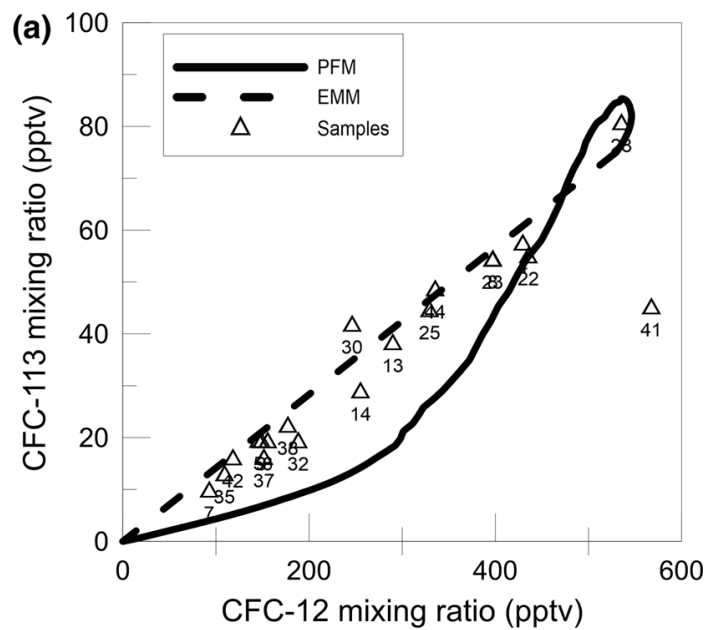

(b)

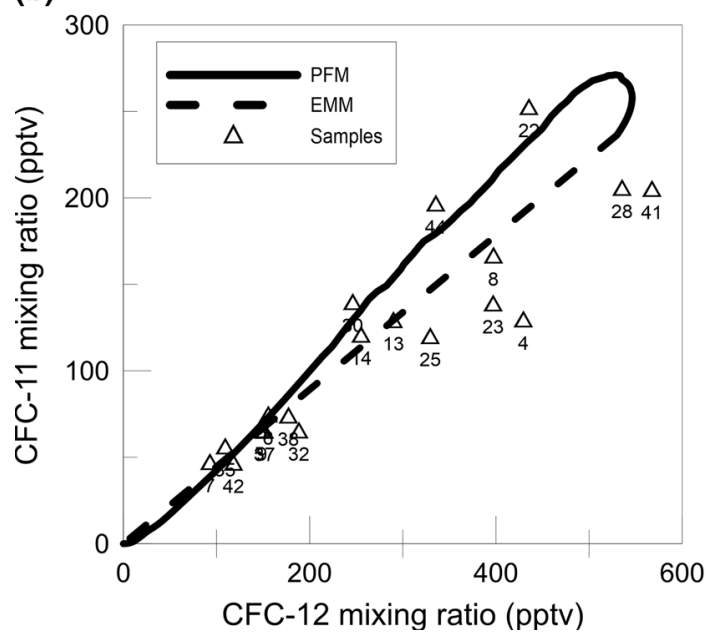

Fig. 8 Tracer plots with selected models curves: a CFC-113 vs. CFC-12 mixing ratios, b tracer plot CFC-11 vs. CFC-12 mixing ratios. $P F M$ piston flow model, EMM exponential mixing model and $4.7 \mathrm{ka})$ are located in the central and western lowlands (El Centenario/Chametla). There is no general positive correlation between groundwater age and temperature; however, the two oldest waters (LP13 and LP25 with 4.0 and $4.7 \mathrm{ka}$, respectively), located in the westernmost portion, coincide with two of highest temperatures in the study area (31.8 and $32.7^{\circ} \mathrm{C}$, respectively) which could indicate local upconing of older groundwater from the lower aquifer unit.

\section{Discussion}

\section{Suitability of environmental tracers}

The geochemical and isotopic investigations show consistency with respect to the hydraulic-head configuration. Generally groundwater moves in SSE-NNW direction from recharge to irrigation areas. Due to heavy abstractions for irrigation, the water table is modified along the coast line, i.e. water table abatement causes seawater intrusion and flow inversion along the coast line. Chloride concentration and TDS increase dramatically near the coast line due to recycling and seawater intrusion rather than as an indication of long RTs.

CFC RTs from the study area calculated using the exponential mixing model tend to become older along the flow path in a SE-NW direction from upper areas to the coast. Similarly to the hydraulic-head configuration, this trend is modified in irrigated areas in the center of the study area where the shortest RTs are observed. The rejuvenation is most likely generated from the irrigation return flow that is continuously recharging the alluvial aquifer. Groundwater from urban and industrial areas sometimes indicates elevated CFC values added from anthropogenic sources (e.g., city samples LP1 and LP11, which appear contaminated).
Fig. 9 a Radiocarbon activity versus ${ }^{13} \mathrm{C}$ ratios, $\mathbf{b}$ radiocarbon activity versus DIC concentration
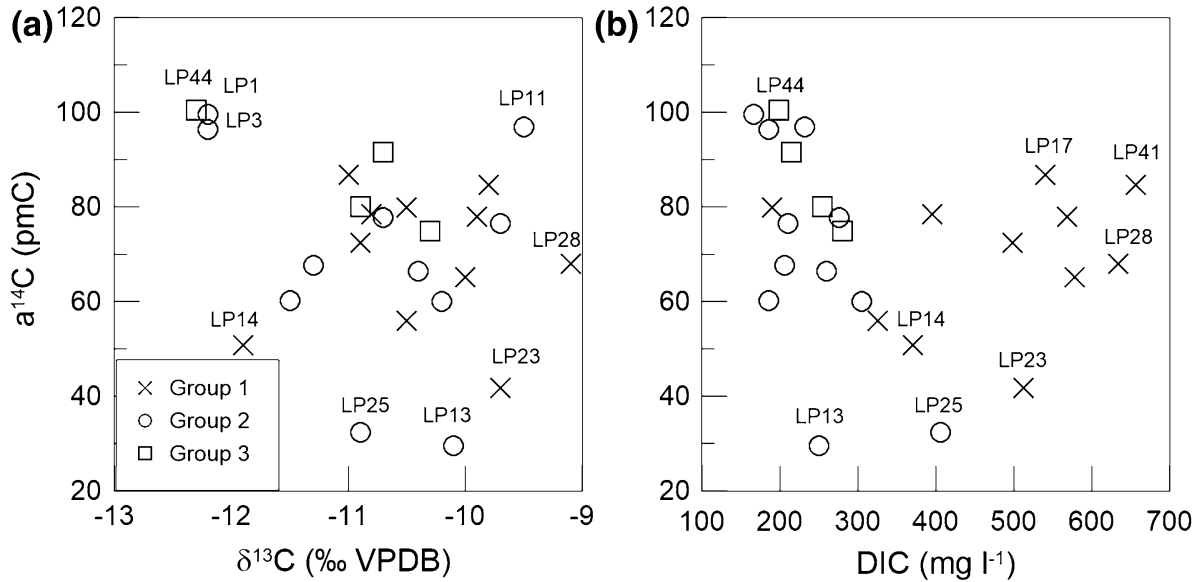
Carbon-14 RTs differ from CFC RTs because the concentrations of anthropogenic atmospheric CFC gases in groundwater provide information on groundwater residence times and mixing processes for waters up to 50 years in age (Goody et al. 2006). In addition, radiocarbon is a tracer that estimates groundwater RTs in the aquifer, integrating all flowpaths and considering degradation of their concentrations. Additionally, the impact of irrigation return flow modifies CFC concentrations substantially, resulting in relatively young RTs that contradict ${ }^{14} \mathrm{C}$ ages in irrigated areas.

\section{Contribution to flow conceptualization}

Stable water isotopes suggest that the primary groundwater recharge of the valley of $\mathrm{La} \mathrm{Paz}$ is originating naturally at higher elevations of the Las Cruces and El Novillo ranges, respectively. Other recharge sources evidenced by stable isotopes and CFCs are irrigation return flow below irrigated lands and seawater intrusion due to an inversion of flow direction along the coastline as a consequence of heavy, uncontrolled extractions. These results corroborate the outcome of a previous study on groundwater recharge based on hydraulic data (Cruz-Falcón et al. 2011). In addition, CFC levels in combination with concentrations of some chemical elements suggest recharge from anthropogenic sources in urbanized areas, while radiocarbon data indicate an upconing of a regional groundwater flow.

Piezometric levels indicate that groundwater moves from natural recharge areas in SSE-NNW direction and discharges in the Sea of Cortez. However, from the decrease of radiocarbon activity observed in this study it can be inferred that groundwater more likely moves in a direction between E-W and SE-NW. In addition, the groundwater table configuration is heavily modified from intensive groundwater extraction. An ever-increasing groundwater level abatement of up to $10 \mathrm{~m}$ is observed below irrigated agricultural areas where groundwater extraction is not controlled. The abatement is corroborated by the observation of radiocarbon and CFC modification in groundwater along the flow gradient.

Spring water reflects cation/anion concentrations typical for water derived from igneous/metamorphic rocks. Total dissolved solids and EC values along groundwater flow sections attain up to $5352 \mathrm{mg} \mathrm{l}^{-1}$ and $8920 \mu \mathrm{S} \mathrm{cm}^{-1}$, respectively. Chloride and sodium exert the major control on salinity. Sodium is primarily released by weathering of Na-feldspars, and $\mathrm{Ca}^{2+}$ is primarily released from plagioclase, hornblendes and pyroxene. The resulting groundwater types are $\mathrm{Ca}-\mathrm{HCO}_{3}$ to $\mathrm{Na}-\mathrm{HCO}_{3}$ as a result of the discordant dissolution of primary silicate minerals and possibly an exchange of $\mathrm{Ca}^{2+}$ for $\mathrm{Na}^{+}$in the soil. In addition, seawater with $\mathrm{Na}^{+}$and $\mathrm{Cl}^{-}$as dominant ions is in contact with sediments from the coastal area and its intrusion induces an exchange of cations on the soil particles where $\mathrm{Na}^{+}$is taken up and $\mathrm{Ca}^{2+}$ is released.

\section{Anthropogenic impact}

The result from excessive pumping and upconing of seawater is a $\mathrm{Ca}-\mathrm{Cl}$ groundwater type and local increase in temperature in the aquifer's center. Groundwater used in agriculture shows increasing $\mathrm{Cl}^{-}$and $\mathrm{Na}^{+}$concentrations as a result of evapotranspiration of irrigation water. The subsequent water type is $\mathrm{Na}-\mathrm{Cl}$ because $\mathrm{Na}^{+}$is exchanged for $\mathrm{Ca}^{2+}$ on the soil exchangers.

Elements of anthropogenic origin such as $\mathrm{NO}_{3}^{-2}$ have a notable distribution in the study area. Elevated concentrations of $\mathrm{NO}_{3}^{-2}$ that exceed the Mexican drinking water standard are located specifically below agricultural lands. In contrast, the impact of domestic sewage from urbanized areas on groundwater is relatively low.

\section{Conclusions}

A study using groundwater chemistry, environmental isotopes and gas tracers was developed to elucidate the dynamics and occurrence of groundwater of a coastal Holocene aquifer. Groundwater is mainly of meteoric origin. Recharge occurs mostly in Las Cruces and Novillo ranges in the $\mathrm{E}$ and SSE portion of the study area, respectively, and flows in NNW direction. While flowing to the discharge area, groundwater acquires salinity from incongruent silicate weathering and evaporation due to the dry climate. Pre-development flow conditions suggest that groundwater discharged in the bay of La Paz Ensenada.

The agricultural development in the central portion of the study area gradually modified the piezometric watertable configuration and chemical conditions. The heavy extractions from irrigation zones in El Centenario, Chametla and south of La Paz provoked an ever growing water balance deficit and consequently water table abatements reaching so far an elevation of up to $\sim 10 \mathrm{~m}$ below sea level in the central part of the study area. On the other hand, this water table decline provokes groundwater recharge from seawater intrusion along the coastline, impacting the water chemistry $13 \mathrm{~km}$ land inwards, i.e. reaching water quality levels in the order of brackish water. Residence time calculations using chlorofluorocarbons and radiocarbon indicate that groundwater is in general modern to submodern.

Other groundwater sources have been identified. Several sites in the western portion demonstrate higher temperatures and fossil water of up to $\sim 4.7 \mathrm{ka}$ which suggests upconing of deeper, regional groundwater flows from 
lower, intrusive rock formations. This indicates that the upper aquifer is locally connected with the lower aquifer units. Likewise, managed aquifer recharge has been detected. Farmers from El Centenario, Chametla and Paraiso del Mar use treated wastewater from La Paz city for irrigation purpose, as part of an agreement with $\mathrm{La} \mathrm{Paz}$ city to exchange water for wastewater.

The anthropogenic impact of groundwater is reflected by the distribution of nitrate and sulfate concentrations, which can be attributed to the general overutilization of fertilizers in agricultural activities. The elevated and increasing levels of chloride and salinity in areas of intensive pumping support the hypothesis that induced mixing and water quality degradation have occurred over relatively short time scales (e.g., decades).

Groundwater degradation is currently a limiting factor for local economic growth, and there is potential for a conflict between agricultural and urban water use. The study contributes to the development of an adequate conceptual and numerical model for simulating the hydrodynamics of the aquifer of the La Paz coastal plain to help water authorities with a decision tool for a sustainable water use.

Acknowledgments This study was co-financed by Fundación FEMSA and the Water Science and Technology chair of Tecnologico de Monterrey. Fundación FEMSA had no role in study design, data collection and analysis, decision to publish, or preparation of the manuscript. We would like to thank R. Ledesma for his assistance in the field work and mapping. Finally, we would like to acknowledge the reviewers for their valuable comments on the initial version of the manuscript.

Open Access This article is distributed under the terms of the Creative Commons Attribution 4.0 International License (http://creative commons.org/licenses/by/4.0/), which permits unrestricted use, distribution, and reproduction in any medium, provided you give appropriate credit to the original author(s) and the source, provide a link to the Creative Commons license, and indicate if changes were made.

\section{References}

Alcalá $\mathrm{FJ}$, Custodio $\mathrm{E}$ (2008) Using the $\mathrm{Cl} / \mathrm{Br}$ ratio as a tracer to identify the origin of salinity in aquifers in Spain and Portugal. J Hydrol 359:189-207

Álvarez AA, Rojas SH, Prieto MJ (1997) Geología de la bahía de la Paz y areas adyacentes. In: Ramírez RM, Urbán RJ (eds) La Bahía de La Paz: Investigación y Conservación. UABCSCICIMAR-SCRIPPS, Mexico, pp 13-29

Anders R, Mendez GO, Futa K, Danskin WR (2014) A geochemical approach to determine sources and movement of saline groundwater in a coastal aquifer. Ground Water 52(5):756-768

Busenberg E, Plummer LN (1992) Use of chlorouorocarbons (CCl3F and $\mathrm{CCl} 2 \mathrm{~F} 2$ ) as hydrologic tracers and age dating tools: the alluvium and terrace system of central Oklaholma. Water Resour Res 28:2257-2283

Cardoso Da Silva J, Bocanegra E, Custodio E, Manzano M, Montenegro S (2010) State of knowledge and management of
Iberoamerican coastal aquifers with different geo-hydrological settings. Episodes 33(2):0705-3797

CIBNOR (Centro de Investigaciones Biológicas del Noroeste), UNAM (Universidad Nacional Autónoma de México) (2011) Modelación de escenarios para el estudio de manejo integrado de las aguas subterraneas en el acuífero de La Paz, B.C.S. La Paz, BCS. UNAM

CIGSA (Consultores en Ingeniería Geofísica SA de CV) (2001) Estudio de caracterización y modelación de la intrusión marina en el acuífero de La Paz BCS. Contrato CNA, GAS-013-PR01. pp 284

Clark D, Fritz P (1997) Environmental isotopes in hydrogeology. CRC Press LLC, Florida

CNA (Comisión Nacional del Agua) (1997) Censo de captaciones de aguas subterráneas y colección de datos geohidrológicos en la zona La Paz-EI Carrizal, BCS. Informe final, Contrato GAS026-PR097 para ADI Construcciones S.A. de C.V. Subdirección General Técnica, Gerencia de Aguas Subterráneas pp 173

CNA (Comisión Nacional del Agua) (1999) Documento de Respaldo para la Publicación de la Disponibilidad. Acuífero BCS.-24 La Paz. Gerencia Regional de la Península de Baja California, Mexicali, B.C. Comisión Nacional del Agua pp 17

CNA (Comisión Nacional del Agua) (2001) Estudio de Caracterización y modelación de la intrusión marina en el acuífero de la Paz B.C.S. México DF, pp 285

CNA (Comisión Nacional del Agua) (2002) Determinación de la disponibilidad de agua en el acuífero de La Paz, Estado de Baja California Sur. Dirección General Técnica. Gerencia de Aguas Subterráneas. Subgerencia de Evaluación y Modelación Hidrogeológica pp 18

CONAGUA (Comisión Nacional del Agua) (2005) Estudio para Actualizar la Disponibilidad Media Anual de las Aguas Nacionales Superficiales en las 85 (ochenta y cinco) Subregiones Hidrológicas de las 7 (siete) Regiones Hidrológicas 1,2,3,4,5,6 y 7 de la Península de Baja California, Mediante la Aplicación de la NOM-011-CNA-2000. Comisión Nacional del Agua p 75

CONAGUA (Comisión Nacional del Agua) (2009) Actualización de la disponibilidad media anual de agua subterránea; Acuífero (0324) La Paz, Estado de Baja California. Diario Oficial de la Federación. CONAGUA Subdirección General Técnica: Gerencia de Aguas Subterráneas, Subgerencia de Evaluación y Ordenamiento de Acuíferos

CONAGUA (Comisión Nacional del Agua) (2010) Situacion actual y posibles escenarios de intrusion salina en el acuifero la paz, baja california sur y su aprovechamiento como fuente de desalacion para abastecimiento de agua potable. Informe Final, Mexico City

CONAGUA (Comisión Nacional del Agua) (2014) Estadísticas del Agua en México. Secretaría de Medio Ambiente y Recursos Naturales, Mexico City. http://www.conagua.gob.mx/CONA GUA07/Publicaciones/Publicaciones/EAM2014.pdf. Accessed 03 July 2015

CONAGUA (Comisión Nacional del Agua), UNAM (Universidad Autónoma de México) (2010) Informe Final: Situación actual y posibles escenarios de intrusión salina en el acuífero La Paz, Baja California Sur y su aprovechamiento como fuente de desalación para abastecimiento de agua potable. p 433

CONAPO (Consejo Nacional de Población) (2014) Datos de proyecciones: Estimaciones y proyecciones de la población por entidad federativa. http://www.conapo.gob.mx/es/CONAPO/Proyec ciones_Datos. Accessed 28 January 2015

Cook PG, Solomon DK, Plummer LN, Busenberg E, Schiff SL (1995) Chlorofluorocarbons as tracers of groundwater transport processes in a shallow, silty sand aquifer. Water Resour Res $31: 425-434$ 
Cruz-Falcón A (2007) Caracterización y diagnóstico del acuífero de la paz, BCS. mediante estudios geofisícos y geohidrológicos. $\mathrm{PhD}$ thesis, Instituto Polítécnico Nacional

Cruz-Falcón A, Vázquez-González R, Ramírez-Hernández J, SalinasGonzález F, Nava-Sánchez EH, Troyo-Diéguez E (2010) Depth estimation to crystalline basement in the valley of La Paz, Baja California Sur, Mexico. Geofísica Int 49(4):213-224

Cruz-Falcón A, Vázquez-González R, Ramírez-Hernández J, NavaSánchez EH, Troyo-Diéguez E, Rosas-Rivera J, Vega-Mayagoitia JE (2011) Rainfall and recharge in the basin of La Paz, BCS, Mexico. Universidad y Ciencia 27(3):251-263 (in Spanish)

Cruz-Falcón A, Ramírez-Hernández J, Vázquez-González R, NavaSánchez EH, Troyo-Diéguez E, Fraga-Palomino HC (2013) Estimación de la recarga y balance hidrológico del acuífero de la Paz, BCS, Mexico. Universidad y Ciencias 29(1):87-100

Cruz-Fuentes T, del Carmen Cabrera M, Heredia J, Custodio E (2014) Groundwater salinity and hydrochemical processes in the volcano-sedimentary aquifer of La Aldea, Gran Canaria, Canary, Islands, Spain. Sci Total Environ 484:154-166

Darling WG, Gooddy DC, MacDonald AM, Morris BL (2012) The practicalities of using CFCs and SF6 for groundwater dating and tracing. Appl Geochem 27:168-1697

Davis SN, Whittemore DO, Fabryka-Martin J (1998) Uses of chloride/bromide ratios in studies of potable water. Ground Water 36(2):338-350

Deines P, Langmuir D, Harmon RS (1974) Stable carbon isotope ratios and the existence of a gas phase in the evolution of carbonate groundwaters. Geochim Cosmochim Acta 38:1147-1164

Edmunds WM, Smedley PL (2000) Residence time indicators in groundwater: the East Midlands Triassic sandstone aquifer. Appl Geochem 15:737-752

Edmunds WM, Guendouz AH, Mamou A, Moulla A, Shand P, Zouari K (2003) Groundwater evolution in the Continental Intercalaire aquifer of souther Algeria and Tunisia: trace elemen and isotopic indicators. Appl Geochem 18:805-822

Escolero O, Torres-Onofre S (2007) Análisis de la Intrusión de Agua de Mar en el acuífero de La Paz. Boletín Geológico y Minero. 118:637-648

Fontes JC, Garnier JM (1979) Determination of the initial ${ }^{14} \mathrm{C}$ activity of total dissolved carbon: a review of the existing models and a new approach. Water Resour Res 15(2):399-413

Gaona-Zanella P (2014) Análisis de Calidad de las Aguas Subterráneas en La Paz, Baja California Sur, como contribución a la Sostenibilidad Hídrica de la Región. MSc thesis, Tecnológico de Monterrey, Monterrey, México

Gardner PM, Heilweil VM (2014) A multitracer approach to understanding regional groundwater flow in the Snake Valley area of the eastern Great Basin, USA. Appl Geochem. doi:10. 1016/j.apgeochem.2014.02.010

Gonçalvès J, Vallet-Coulomb C, Petersen J, Hamelin B, Deschamps P (2015) Declining water budget in a deep regional aquifer assessed by geostatistical simulations of stable isotopes: case study of the Saharan "Continental Intercalaire". J Hydrol 531:821-829

Goody DC, Darling WG, Abesser C, Lapworth DJ (2006) Using chlorofluorocarbons (CFCs) and sulphur hexafluoride (SF6) to characterise groundwater movement and residence time in a lowland Chalk catchment. J Hydrol 330:44-52

Han DM, Song XF, Currell MJ, Yang JL, Xiao GQ (2014) Chemical and isotopic constraints on evolution of groundwater salinization in the coastal plain aquifer of Laizhou Bay, China. J Hydrol 508:12-27

Hem JD (1989) Study and interpretation of the chemical characteristics of natural water. US Geological Survey, Water Supply Paper 2254
Hernández-Antonio A, Mahlknecht J, Tamez-Meléndez C, RamosLeal J, Ramírez-Orozco A, Parra R, Ornelas-Soto N, Eastoe CJ (2015) Groundwater flow processes and mixing in active volcanic systems: the case of Guadalajara (Mexico). Hydrol Earth Syst Sci 19:3937-3950

Horst A, Mahlknecht J, Merkel B (2007) A stable isotope (strontium, carbon, deuterium, oxygen-18) study for detecting mixing and origin in an overexploited aquifer in Mexico. Isot Environ Health Stud 43(4):323-338

Horst A, Mahlknecht J, Merkel BJ, Aravena R, Ramon-Arroyo YR (2008) Evaluation of the recharge processes and impacts of irrigation on groundwater using CFCs and radiogenic isotopes in the Silao-Romita basin, Mexico. Hydrogeol J 16:1601-1614

IAEA (International Atomic Energy Agency) (1996) Manual on Mathematical Models in Isotope Hydrogeology. IAEA-TECDOC-910, Vienna, Austria, pp 207

IAEA (International Atomic Energy Agency) (2006) Use of Chlorofluorocarbons in Hydrology: A Guidebook. IAEA Library Cataloguing in Publication Data, Vienna, Austria, p 277

ICF (International Community Foundation), Fundación FEMSA, GeoAdaptive LLC (2012) La Paz, Ciudad Sostenible: Reporte Sistema de Indicadores para la Plataforma de Ciudades Emergentes y Sostenibles. Banco Interamericano de Desarrollo, Cambridge

INEGI (Instituto Nacional de Estadística Geografía e Informática) (2005) Superficie total por distrito de desarrollo rural y municipio según uso de suelo y vegetación. http://www. oeidrus-bcs.gob.mx/. Accessed 1 April 2015

Ingerson E, Pearson FJ (1964) Estimation of age and rate of motion of groundwater by the ${ }^{14} \mathrm{C}$-method. Recent Researches in the Fields of Hydrosphere. Atmosphere and Nuclear Geochemistry Maruzen, Tokyo, pp 263-283

Jiménez-Martínez J, Custodio E (2008) El exceso de deuterio en la lluvia y en la recarga a los acuíferos en el área circummediterránea y en la costa mediterránea española. Boletín Geológico y Minero 119(1):21-32

Kaown D, Koh DC, Lee KK (2009) Effects of groundwater residence time and recharge rate on nitrate contamination deduced from $\delta^{18} \mathrm{O}, \delta \mathrm{D},{ }^{3} \mathrm{H} /{ }^{3} \mathrm{He}$ and $\mathrm{CFCs}$ in a small agricultural area in Chuncheon, Korea. J Hydrol 366(1-4):101-111

Kaplan D, Muñoz-Carpena R (2014) Groundwater salinity in a floodplain forest impacted by saltwater intrusion. J Contam Hydrol 169:19-36

Kusano Y, Tokunaga T, Asai K, Takahashi HA, Morikawa N, Yasuhara M (2014) Occurrence of old groundwater in a volcanic island on a continental shelf: an example from Nakano-shima Island. Oki-Dozen, Japan

Ledesma-Ruiz R, Pastén-Zapata E, Parra R, Harter T, Mahlknecht J (2015) Investigation of the geochemical evolution of groundwater under agricultural land: a case study in northeastern Mexico. J Hydrol 521:410-423

Lindsey BD, Phillips SW, Donnelly CA, Speiran GK, Plummer LN, Boehlke JK, Focazio MJ, Burton WC, Busenberg E (2003) Residence times and nitrate transport in ground water discharging to streams in the chesapeake bay watershed, water-resources investigations Rep. 03-4035, US Geological Survey, New Cumberland, PA

Mahlknecht J, Steinich B, Navarro de León I (2004) Groundwater chemistry and mass transfers in the Independence aquifer, central Mexico, by using multivariate statistics and mass-balance models. Environ Geol 45(6):781-795

Mahlknecht J, Garfias-Solis J, Aravena R, Tesch R (2006a) Geochemical and isotopic investigations on groundwater residence time and flow in the Independence Basin, Mexico. J Hydrol 324:283-300 
Mahlknecht J, Medina-Mejía MG, Gárfias-Solis J, Cano-Aguilera I (2006b) Intrinsic aquifer vulnerability assessment: validation by environmental tracers in San Miguel de Allende, Mexico. Environ Geol 51(3):477-491

Michener R, Lajtha K (2007) Stable isotopes in ecology and environmental science. Blackwel, London

Minitab (2013) Getting started with minitab 17. United States: Minitab Inc. Retrieved from http://www.minitab.com

Mohammed N, Celle-Jeanton Huneau F, Le Coustumer P, Lavastre V, Bertrand G, Charrier G, Clauzet ML (2014) Isotopic and geochemical identification of main groundwater supply sources to an alluvial aquifer, the Allier River valley (France). J Hydrol 508:181-196

Monzalvo M (2010) Simulación hidrodinámica del acuífero de La Paz y su aprovechamiento como fuente de desalación. PhD thesis, Universidad Nacional Autónoma de México, Mexico City

Mook WG, Bommerson JC, Staverman WH (1974) Carbon isotope fractionation between dissolved bicarbonate and gaseous carbon dioxide. Earth Planet Sci Lett. doi:10.1016/0012$821 X(74) 90078-8$

Noroeste PRONATURA (2010) Diagnóstico de la Cuenca de la Paz: Reporte Final del Convenio Niparaja. Programa Agua y Humedales, La Paz, BCS, Mexico

Oster H, Sonntag C, Münnich KO (1996) Groundwater age dating with chlorofluorocarbons. Water Resour Res 37:2989-3001

Perea MC, Ezcurra E, León de la Luz JL (2005) Functional morphology of a sarcocaulescent desert scrub in the bay of La Paz, Baja California Sur, Mexico. J Arid Environ 62(3):413-426

Plummer LN (2003) Environmental tracers and how they are used to understand the aquifer. In: Bartolino JR, Cole JC (eds) Geological Survey Circular 1222

Plummer LN (2005) Dating of young groundwater. In: Aggarwal PK, Gat JR, Froehlich K (eds) Isotopes in the water cycle. Springer, Netherlands, pp 193-218

Plummer LN, Busenberg E (2000) Chlorofluorocarbons: Tools for dating and tracing young groundwater. In: Cook P, Herczeg A (eds) Environmental Tracers in Subsurface Hydrology. Kluwer Academic Publishers, Boston, pp 441-478

Plummer LN, Busenberg E, Drenkard S, Schlosser P, Ekwurzel B, Weppernig R, McConnell JB, Michel RL (1998) Flow of river water into a karstic limestone aquifer, 2. Dating the young fraction in groundwater mixtures in the Upper Floridan aquifer near Valdosta, Georgia. Appl Geochem 13(8):1017-1043

Plummer LN, Busenberg E, Böhlke JK, Nelms DL, Michel RL, Schlosser P (2001) Groundwater residence times in Shenan-doah National Park, Blue Ridge Mountains, Virginia, USA: a multitracer approach. Chem Geol 179(1-4):93-111

Post VEA (2005) Fresh and saline groundwater interaction in coastal aquifers: is our technology ready for the problems ahead? Hydrol J. doi:10.1007/s10040-004-0417-2pp120-123

Rindsberger M, Margaritz M, Carmi I, Gilad D (1983) The relation between air mass trajectories and the waterisotopic composition in the Mediterranean Sea area. Geophysical Rev. Lett. 10:43-46

Rodríguez-Estrella R, Donázar A, Hiraldo F (1998) Raptors as indicators of environmental change in the scrub habitat of Baja California Sur, Mexico. Conserv Biol 12:921-925

Russak A, Yechieli Y, Herut B, Lazar B, Sivan O (2015) The effect of salinization and freshening events in coastal aquifers on nutrient characteristics as deduced from field data. J Hydrol 529:1293-1301

Solomon DK, Genereux DP, Plummer NL, Busenberg E (2010) Testing mixing models of old and young groundwater in a tropical lowland rain forest with environmental tracers. Water Resour Res. doi:10.1029/2009WR008341

Unsal B, Yagbasan O, Yazicigil H (2014) Assessing the impacts of climate change on sustainable management of coastal aquifers. Environ Earth Sci 72:2183-2193

USGS (United States Geology Survey) (2014) The reston groundwater dating laboratory. http://water.usgs.gov/lab/software/air curve/index.html. Accessed 2nd February 2014

Vogel JC, Grootes PM, Mook WG (1970) Isotope fractionation between gaseous and dissolved carbon dioxide. Z. Phys. doi:10. 1007/BF01394688

Ward J (1963) Hierarchical grouping to optimize an objective function. J Am Stat Assoc 17:24:12 (pp 236-244)

Wassenaar LI, Van Wilgenburg SL, Larson K, Hobson K (2009) A groundwater isoscape $\left(\delta \mathrm{D}, \delta^{18} \mathrm{O}\right)$ for Mexico. J Geochem Explor 102:123-136 